\title{
Serum and Glucocorticoid Regulated Kinase 1 in Sodium Homeostasis
}

\author{
Yiyun Lou ${ }^{1,2}$, Fan Zhang ${ }^{1}$, Yuqin Luo ${ }^{1}$, Liya Wang ${ }^{1}$, Shisi Huang ${ }^{1}$ and Fan Jin ${ }^{1,3, *}$ \\ 1 Department of Reproductive Endocrinology, Women's Hospital, School of Medicine, Zhejiang University, \\ Hangzhou 310006, Zhejiang, China; louyiyun@zju.edu.cn (Y.L.); zhangfanchina@zju.edu.cn (F.Z.); \\ szyck@zju.edu.cn (Y.Lu.); wangliya@zju.edu.cn (L.W.); huangshisi@zju.edu.cn (S.H.) \\ 2 Department of Gynaecology, Hangzhou Hospital of Traditional Chinese Medicine, \\ Hangzhou 310007, Zhejiang, China \\ 3 Key Laboratory of Reproductive Genetics, National Ministry of Education (Zhejiang University), \\ Women's Reproductive Healthy Laboratory of Zhejiang Province, Hangzhou 310058, Zhejiang, China \\ * Correspondence: jinfan@zju.edu.cn; Tel.: +86-571-8701-3891; Fax: +86-571-8706-1878
}

Academic Editor: Atsushi Matsuzawa

Received: 15 June 2016; Accepted: 3 August 2016; Published: 10 August 2016

\begin{abstract}
The ubiquitously expressed serum and glucocorticoid regulated kinase 1 (SGK1) is tightly regulated by osmotic and hormonal signals, including glucocorticoids and mineralocorticoids. Recently, SGK1 has been implicated as a signal hub for the regulation of sodium transport. SGK1 modulates the activities of multiple ion channels and carriers, such as epithelial sodium channel $(\mathrm{ENaC})$, voltage-gated sodium channel (Nav1.5), sodium hydrogen exchangers 1 and 3 (NHE1 and NHE3), sodium-chloride symporter (NCC), and sodium-potassium-chloride cotransporter 2 (NKCC2); as well as the sodium-potassium adenosine triphosphatase $\left(\mathrm{Na}^{+} / \mathrm{K}^{+}\right.$-ATPase) and type A natriuretic peptide receptor (NPR-A). Accordingly, SGK1 is implicated in the physiology and pathophysiology of $\mathrm{Na}^{+}$homeostasis. Here, we focus particularly on recent findings of SGK1's involvement in $\mathrm{Na}^{+}$transport in renal sodium reabsorption, hormone-stimulated salt appetite and fluid balance and discuss the abnormal SGK1-mediated $\mathrm{Na}^{+}$reabsorption in hypertension, heart disease, edema with diabetes, and embryo implantation failure.
\end{abstract}

Keywords: serum and glucocorticoid regulated kinase 1 (SGK1); epithelial sodium channels; voltage-gated sodium channels; hypertension; edema; heart disease; embryo implantation

\section{Introduction}

Serum and glucocorticoid regulated kinase 1 (SGK1) was originally isolated in a differential screen searching for glucocorticoid-inducible transcripts in Con8.hd6 rat mammary tumor cells [1,2]. Within $30 \mathrm{~min}$, SGK1 transcript levels were altered strongly upon cell volume change, independent of de novo protein synthesis [3]. SGK1 is highly conserved throughout eukaryotic evolution [4], being identified in the genomes of various species [5-15]. Human SGK1 is ubiquitously expressed throughout the whole body (Table 1). 
Table 1. Serum and glucocorticoid regulated kinase 1 (SGK1) expressions throughout the body.

\begin{tabular}{|c|c|c|}
\hline Organ & Distribution of $S G K 1$ & Reference \\
\hline \multirow{6}{*}{ Brian } & Hypothalamic nuclei & [16] \\
\hline & Ventral striatum & [17] \\
\hline & Dorsal horn & [18] \\
\hline & Dopamine neurons & [19] \\
\hline & Cortical pyramidal neurones & [20] \\
\hline & Blood-brain barrier (BBB) & [21] \\
\hline \multirow{2}{*}{ Eye } & Ocular ciliary epithelium & [22] \\
\hline & Corneal endothelium & [23] \\
\hline \multirow[b]{2}{*}{ Ear } & Cochlear sensory epithelium & [24] \\
\hline & Apical membrane of middle ear epithelium & [25] \\
\hline Thymus & Epithelial cell & [2] \\
\hline Heart & Heart chamber & [26] \\
\hline Lung & Epithelial cell & [27] \\
\hline Breast & Mammary gland & [28] \\
\hline Liver & Epithelial cell & [29] \\
\hline Pancreas & Pancreatic tissue & [30] \\
\hline Intestine & Epithelium of the duodenum, jejunum, ileum, and colon & [31] \\
\hline Kidney & Epithelium lining the nephrons (distal tubules, glomeruli, and inner medulla) & [32] \\
\hline Bladder & Detrusor tissue & [19] \\
\hline Muscle & Skeletal muscle & [33] \\
\hline Adipose tissue & Adipocyte & {$[34,35]$} \\
\hline Blood & Platelets & {$[36,37]$} \\
\hline \multirow{4}{*}{ Immune system } & T-lymphocytes & [38] \\
\hline & Dendritic cell & [39] \\
\hline & Macrophage & [40] \\
\hline & Mast cell & [41] \\
\hline \multirow{5}{*}{$\begin{array}{l}\text { Reproductive } \\
\text { system }\end{array}$} & Several ovarian cell types including the oocytes of primordial follicles & [42] \\
\hline & Sperm & [43] \\
\hline & Primordial germ cell & [44] \\
\hline & Decidua & [45] \\
\hline & Placental trophoblast & [46] \\
\hline
\end{tabular}

As a serine-threonine protein kinase, SGK1 belongs to the protein kinase A/protein kinase G/protein kinase C (AGC) family, and is expressed at low levels under physiological conditions [47-49]. Both its expression levels and activities are regulated by hormonal and non-hormonal factors [50], including glucocorticoids [51,52], mineralocorticoids [16,42], androgen [53-56], gonadotropin-releasing hormone (GnRH) [57], excessive extracellular glucose concentrations [58,59], memory consolidation and reconsolidation [60], hypertonic and hypotonic stimuli [61], chronic stress [52], and peroxisome proliferator-activated receptor $\gamma$ (PPAR $\gamma$ ) [62]. SGK1 is also induced by lipopolysaccharides [63], tumor necrosis factor (TNF)- $\alpha$ [63,64], angiotensin [65], resistin [66], granulocyte-macrophage colony-stimulating factor (GM-CSF) [67], fibroblast growth factor-23 (FGF23) [68], as well as miR-27a [24], miR-424 [69], miR-155 [70] and miR-133b [71]. Under stimulation by transforming growth factor (TGF)- $\beta$ [72,73] and insulin [74], SGK1 is phosphorylated via signaling pathways involving phosphatidylinositol 3-kinase (PI3K), 3-phosphoinositide-dependent kinases (PDK1) [74] and mammalian target of rapamycin complex 2 (mTORC2) [75,76]. By contrast, interleukin-6 (IL-6) induces SGK1 transcription mainly through the janus kinase/signal transducer and activator of transcription (JAK/STAT) cascade [77]. These genomic and non-genomic activations of SGK1 contribute to the regulation of multiple epithelial ion channels, several ion carriers, and many other molecules [78]. 
The first demonstrated physiologically relevant function of SGK1 was its regulation of $\mathrm{ENaC}-$ mediated $\mathrm{Na}^{+}$transport [79]. The present review attempts to delineate the current knowledge on the physiological and pathophysiological significance regarding SGK1 in the regulation of $\mathrm{Na}^{+}$homeostasis.

\section{Serum and Glucocorticoid Regulated Kinase 1 (SGK1)-Dependent Regulation of $\mathrm{Na}^{+}$ Channels and Transporters}

\subsection{Epithelial Sodium Channel ( $\mathrm{NaC})$}

Over the past 20 years, SGK1 has emerged as a key modulator of ENaC in the aldosterone-sensitive distal nephron (ASDN) [80], hepatocytes [81], lung [82], corneal layers [22], and brain [83]. SGK1 increases the amiloride-sensitive $\mathrm{Na}^{+}$current significantly in Xenopus laevis oocytes [81,84], mouse collecting duct cells (mpkCCD $\mathrm{cl}_{4}$ ) [85], mammalian M1-CCD cells [86], amphibian A6 cell line [87,88], COS7 cells [89], H441 human airway epithelial cells [90,91], and colonic HT-29/B6 cells [92].

Upon stimulations of hormonal and non-hormonal signals, SGK1 regulates $\mathrm{Na}^{+}$transport in various cells by altering ENaC expression [93,94], enhancing this channel's activity and open probability $\left(P_{\mathrm{o}}\right)$ [95], facilitating ENaC channel trafficking, and attenuating its degradation and recycling [96].

Several mechanisms have been proposed for the SGK1-dependent regulation of ENaC [82,97]. The best understood explanation argues that aldosterone-induced SGK1 increases ENaC activity indirectly by reducing ubiquitination of $\mathrm{ENaC}$ via phosphorylation and inhibition of the $\mathrm{E} 3$ ubiquitin ligase neuronal precursor cell expressed developmentally down-regulated 4-2 (Nedd4-2) [93], which results in increased $\mathrm{Na}^{+}$transport in Xenopus laevis oocyte. SGK1 phosphorylates specific residues of Nedd4-2, resulting in the recruitment of the 14-3-3 protein, which inhibits the interaction between Nedd4-2 and ENaC. This inhibition is dependent on SGK1-catalyzed phosphorylation of Nedd4-2 [98,99]. Consistent with this view, GSK650394, an SGK1 inhibitor, suppresses the dexamethasone-induced phosphorylation of Nedd4-2, and reduces the surface abundance of $\alpha$ subunit of ENaC in airway epithelial cells [91]. Therefore, SGK1 phosphorylates the negative regulator Nedd4-2 and recruits $14-3-3$, thereby preventing the ubiquitination and subsequent internalization of ENaC, and inhibiting the removal of the channel. This results in accumulation of $\mathrm{ENaC}$ at the cell surface and increased $\mathrm{Na}^{+}$reabsorption as reviewed in [100-105].

In the above model, $\mathrm{ENaC}$, possibly with cholesterol, recruits proteins to form the $\mathrm{ENaC}$-regulatory complex (ERC) for its own regulation [106,107]. In this respect, Soundararajan et al. [108] have identified an approximately 1.0-1.2 MDa ENaC-regulatory-complex (ERC) containing ENaC and certain key regulatory factors, including aldosterone-regulated SGK1, Nedd4-2, v-raf-1 murine leukemia viral oncogene homolog 1 (c-Raf), glucocorticoid-induced leucine zipper (GILZ1), and the connector enhancer of kinase suppressor of Ras isoform 3 (CNK3), at the plasma membrane in mpkCCD ${ }_{\text {c14 }}$ cells $[107,108]$. GILZ1 physically interacts with SGK1 to alter its subcellular localization and selectively recruits it into the ERC [106]. Contrastingly, CNK3 reinforces the interactions within this complex, providing a platform to assemble the multiprotein ERC to trigger $\mathrm{ENaC}$ activation [108-110].

Moreover, IкB kinase- $\beta$ (IKK $\beta$ ) was shown recently to enhance $\mathrm{ENaC}$ surface expression by phosphorylating Nedd4-2 on the same site phosphorylated by SGK1 [111,112]. Stimulated by serum in MDA231 cells derived from human breast cancer [113] or using morpholino oligonuleotides against SGK1 in Xenopus laevis oocyte [114], SGK1 was demonstrated to function upstream of IKK $\beta$; therefore, SGK1 could modulate the activities of Nedd4-2 in concert with IKK $\beta$, contributing to the enhanced accumulation of ENaC channel at the apical membrane [98,111].

While the SGK1/Nedd4-2 pathway could lead to enhanced ENaC function [101,111], other studies point to alternative pathways for SGK1 to regulate ENaC activity, independently of Nedd4-2 [110,115]. In this regard, recombinant SGK1 has been shown to directly phosphorylate residue serine (Ser)-621 of the SGK1 consensus motif in the $\mathrm{C}$ terminus tail of $\alpha$-ENaC in Xenopus laevis oocytes, contributing to the activation of $\mathrm{ENaC}$ channels that are already present in the plasma membrane [116]. 
Recent evidence has demonstrated that SGK1 also has a role in aldosterone-stimulated ENaC trafficking in mCCD cells. This mode of channel regulation involves the Rab GAP (GTPase activating protein) AS160, Akt/PKB substrate of $160 \mathrm{kDa}$, which stabilizes $\mathrm{ENaC}$ in a regulated intracellular compartment [117]. Upon SGK1 phosphorylation, AS160 promotes ENaC trafficking to the apical membrane by relieving stabilization of $\mathrm{ENaC}$ in the intracellular compartment, thus augmenting $\mathrm{Na}^{+}$ absorption [117]. In addition, FLAG-tagged SGK1 has been implicated in the regulation of ENaC in HEK293 cells by phosphorylating and thus inhibiting with no lysine kinase 4 (WNK4) [118,119], a serine/threonine kinase that inhibits ENaC activity [120]. SGK1 further regulates ENaC indirectly by phosphorylating inducible nitric oxide synthase (iNOS) [121]. Nitric oxide (NO) inhibits ENaC by reducing its $P_{\mathrm{o}}$ without altering the apparent channel density or $\mathrm{Na}^{+}$current $[121,122]$. Upon the stimulation of aldosterone, SGK1 phosphorylates mouse iNOS and consequently decreases NO produced by iNOS to increase $\mathrm{Na}^{+}$transport in the mouse alveolar type II (ATII) epithelial cells [121].

SGK1 is proposed to up-regulate [123] or de-repress [124] the components of the $\mathrm{Na}^{+}$transport machinery per se, primarily $\alpha$-ENaC. Evidence from $S g k 1$ knockout mice and mouse inner medullary collecting duct cell (mIMCD3) indicated that aldosterone-induced SGK1 is involved in an epigenetic pathway regulating the transcription of SCCH1A (gene encoding $\alpha$-ENaC) by diminishing hypermethylation of histone protein $\mathrm{H} 3$ at lysine 79 (H3K79) in the vicinity of the SCCH1A promoter [124]. SGK1 phosphorylates DNA-binding protein ALL1 fused gene from chromosome 9 (AF9), and thus promotes methyltransferase Disruptor of telomeric silencing 1 (Dot1a) to dissociate from the SCCH1A promoter, leading to inhibition of histone H3K79 methylation at the promoter and subsequently relief of repression [124-126]. Interestingly ALL-1 partner at 17q21 (AF17), a competitor of AF9 for binding Dot1a, relieves Dot1a-AF9 repression as well as increasing SGK1 expression to enhance SGK1-mediated AF9 phosphorylation, resulting in augmented ENaC-mediated $\mathrm{Na}^{+}$transport [127-131].

Taken together, SGK1 regulates ENaC activity through Nedd4-2-dependent and Nedd4-2independent mechanisms [101,111] (Figure 1). These mechanisms are not mutually exclusive. Upon the stimulation of hormonal (e.g., aldosterone, dexamethasone) or non-hormonal (e.g., serum) signals, the activation of SGK1 attenuates the degradation of ENaC to increase the surface abundance of this $\mathrm{Na}^{+}$channel at the apical membrane $[91,93,106,113,114,118,119]$, relieves the stabilization of $\mathrm{ENaC}$ in a regulated intracellular compartment [117], and facilitates ENaC activities by direct phosphorylation $[116,117]$ in various cell lines. Moreover, aldosterone-induced SGK1 has long-term effect on the transcriptional expression of $\mathrm{ENaC}$ in an epigenetic pathway both in vivo and in vitro [124]. The discrepancies among the various mechanisms could be ascribed to the characteristics of different stimuli and the timing of SGK1's action. 


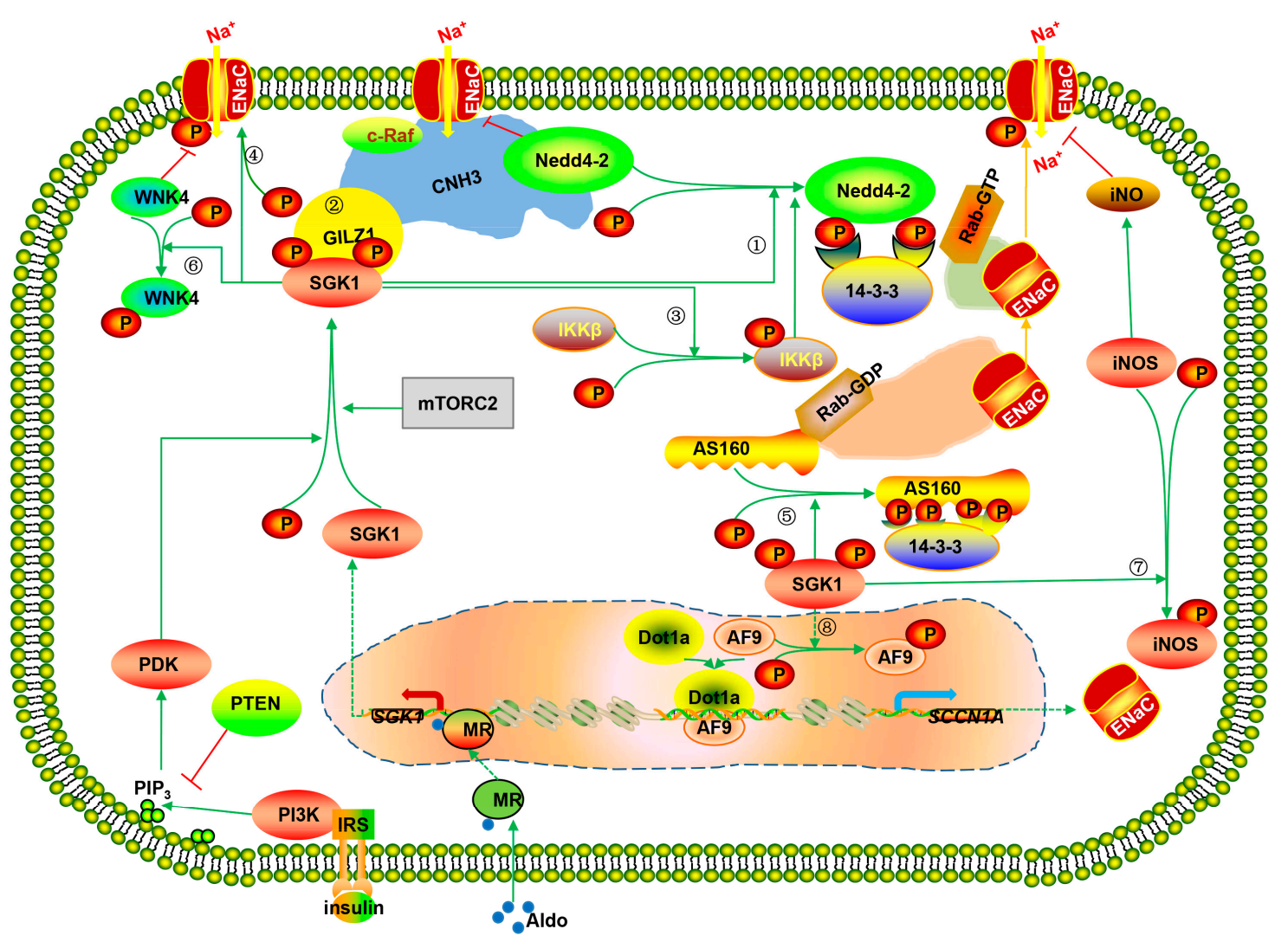

Figure 1. Serum and Glucocorticoid Regulated Kinase1 (SGK1)-dependent regulation of ENaC channel. (1) SGK1 phosphorylates the negative regulator Nedd4-2 and recruits 14-3-3 protein to reduce the ubiquitylation and degradation of ENaC; (2) SGK1 interacts with GILZ1, CNK3, c-Raf, $\mathrm{ENaC}$ and Nedd4-2 to form the ENaC-regulatory complex (ERC) for stimulating ENaC function; (3) SGK1 phosphorylates IKK $\beta$ to reverse the Nedd4-2-mediated inhibition of ENaC; (4) SGK1 directly phosphorylates $\alpha$ subunit of ENaC; (5) SGK1 phosphorylates AS160 to promote ENaC trafficking to the apical cell membrane; (6) SGK1 activates ENaC via phosphorylating WNK4; (7) SGK1 enhances the open probability of ENaC channel by decreasing inhibitory NO through phosphorylating iNOs; and (8) SGK1 is involved in an epigenetic pathway regulating SCCH1A (gene encoded $\alpha-E N a C$ ) transcription by phosphorylating AF9 and promoting Dot1a to dissociate from SCCH1A promoter, diminishing the hypermethylation of histone H3K79 methylation at the promoter of SCCH1A. The translocations of moleculars are marked in dashed arrows. The red arrows with flat head mean inhibitory modification. P, phosphate; PTEN, phosphatase and tensin homolog; IRS, insulin receptor substrate; MR, mineralocorticoid receptor; Aldo, aldosterone.

\subsection{Voltage-Gated $\mathrm{Na}^{+}$Channel Nav1.5 (SCN5A)}

The voltage-gated sodium channel Nav1.5 (encoded by the SCN5A gene), is the major $\mathrm{Na}^{+}$influx channel for the cardiac action potential initiation of cardiac action [132]. As shown in Xenopus laevis oocytes, SGK1 up-regulates cardiac Nav1.5 [97,133]. Through phosphorylation and inactivation of Nedd4-2, SGK1 attenuates the inhibition on Nav1.5 by Nedd4-2, and alters channel trafficking, resulting in an increase in available Nav1.5 channels at the cell surface [97,133-135]. Conversely, inhibition of SGK1 in the dominant-negative $S g k 1$ mice blocked the biochemical changes in Nav1.5 [134]. In addition, peptide mapping identified three putative phosphorylation sites for SGK1 within the Nav1.5 sequence $[132,134]$. The mutation of serine to alanine in the SGK consensus sequences of Nav1.5 resulted in a reversal of the gating properties of the channel $[97,133]$. More recently, Bezzerizes et al. [132] observed that an alanine mutant abolished the increase in $\mathrm{Na}^{+}$current from SGK1 
activation. Thus SGK1 might modify the gating kinetics of Nav1.5 channels by direct phosphorylation of the channel protein [97].

\subsection{Sodium Hydrogen Exchanger (NHE1 and NHE3)}

NHE3 participates in $\mathrm{Na}^{+}$reabsorption and $\mathrm{H}^{+}$secretion in a variety of epithelia and is involved in the modulation of cytosolic $\mathrm{pH}$ in various epithelial and non-epithelial cells [48,136-138]. In cultured epithelial cells, SGK1 enhances NHE3 activity acutely $[139,140]$. SGK1 specifically phosphorylates NHE3 at Ser-663 in response to dexamethasone; therefore, mutation of Ser-663 abolished the stimulatory effect of dexamethasone on NHE3 transport activity [139]. This up-regulation requires the additional presence of the NHE regulatory protein 2 (NHERF2) [141], which tethers NHE3 and SGK1 to aid the phosphorylation of NHE3. Comparing short-term regulation of NHE3 by dexamethasone in Sgk1 flox/flox:Villin-Cre mice and Nherf2 ${ }^{-/-}$mice, He et al. [142] showed that SGK1 plays a major role in acute regulation of NHE3 in vivo in the intestine.

Critically, SGK1 participates in the up-regulation of NHE1 by glucocorticoids in HL-1 cardiomyocytes in vivo [143,144]. Activation of NHE1 could induce cardiac hypertrophy and unbalanced cardiomyocyte $\mathrm{pH}$, which may lead to myocardial remodeling and ischemic cardiac diseases [145-147]. SGK1 presumably phosphorylates NHE1 at Ser-703, promoting 14-3-3 binding and stimulating NHE1 activity by decreasing dephosphorylation and by stabilizing an active conformation of the exchanger $[50,143]$. Stimulated by dexamethasone, SGK1 would participate in the development of heart failure and other cardiac pathophysiology by activating cardiac NHE1 [143].

\subsection{Sodium-Chloride Symporter (NCC)}

The $\mathrm{Na}^{+}-\mathrm{Cl}^{-}$cotransporter, sodium-chloride symporter (NCC), is expressed in the apical plasma membrane of epithelial cells in the distal convoluted tubule (DCT) $[148,149]$. NCC reabsorption accounts for only $5 \%-10 \%$ of filtered $\mathrm{Na}^{+}$; however, is critical to the fine-tuning of renal sodium excretion in response to various hormonal and non-hormonal stimuli $[149,150]$. NCC can be regulated by changes in expression, trafficking and phosphorylation [151].

The total $S g k 1$ knockout mice generated by Fejes-Tóth et al. [80] exhibited a salt-wasting phenotype under a low salt diet, had reduced $\mathrm{ENaC}$ expression and decreased expression of NCC [84]. This phenotype was similar to that of kidney-specific Sgk1 knockout mice [80]. Furthermore, on a low- $\mathrm{NaCl}$ diet, NCC abundance in the DCT of normal mice increased as did phosphorylation of NCC at Thr-53, Thr-58, and Ser-71 [148]. This response, however, is attenuated in mice lacking Sgk1 $\left(S g k 1^{-/-}\right)$, suggesting that Sgk1 somehow affects NCC phosphorylation [148].

SGK1 is thought to modulate NCC activity by inhibiting WNK4 [120,149,152]. WNK4 negatively regulates the surface abundance of NCC by promoting lysosomal degradation [153]. Moreover, WNK4 has been demonstrated to reduce NCC abundance at the plasma membrane, resulting in the inactivation of NCC [154]. Constitutively active SGK1 S422D phosphorylates WNK4 at Ser-1169 [118] and Ser-1196 [155], relieving the inhibitory effect of WNK4 on NCC's activity [149,151].

In addition, aldosterone acutely stimulated $\mathrm{Na}^{+}$reabsorption by NCC in the DCT, and this effect appeared to be dependent upon the presence of SGK1 and Nedd4-2 [156,157]. Accordingly, SGK1 has been proposed to be involved in the regulation of NCC by Nedd4-2 [158]. Similar to ENaC, Nedd4-2 is co-located with NCC and stimulates NCC ubiquitination at the apical plasma membrane. Phosphorylation of Nedd4-2 at Ser-328 and Ser-222 by SGK1 abrogates Nedd4-2-mediated inhibition of NCC [156]. Roy et al. proposed that SGK1 and Nedd4-2 cannot alter the phosphorylation status of NCC in WNK1 KO HEK-293T cells, representing another model of the effects of WNK1 deletion on Nedd4-2/SGK1 regulation of NCC [150]. 


\section{5. $\mathrm{Na}^{+}-\mathrm{K}^{+}-2 \mathrm{Cl}^{-}$Cotransporter (NKCC2)}

SGK1 is not only involved in the regulation of $\mathrm{ENaC}$, but also influences other renal tubular $\mathrm{Na}^{+}$ transport systems [159]. The $\mathrm{Na}^{+}-\mathrm{K}^{+}-2 \mathrm{Cl}^{-}$cotransporter (NKCC2 or BSC-1) is one of the candidate downstream effectors. NKCC2 plays a critical role in $\mathrm{Na}^{+}$reabsorption and urinary $\mathrm{K}^{+}$excretion across the luminal membrane of the thick ascending limb (TAL) [160]. NKCC2-mediated $\mathrm{Na}^{+}$flux was stimulated 6-fold by the co-expression of SGK1 in Xenopus laevis oocytes [161]. Stimulated by the increased extracellular glucose concentrations, the enhanced expression of SGK1 may contribute to the abnormal $\mathrm{Na}^{+}$transport in diabetic nephropathy by regulating NKCC2 [160].

\subsection{Sodium/Potassium-Adenosine Triphosphatase $\left(\mathrm{Na}^{+} / \mathrm{K}^{+}\right.$-ATPase)}

SGK1 has also been implicated in the regulation of $\mathrm{Na}^{+} / \mathrm{K}^{+}$-ATPase activity, the transporter responsible for basolateral $\mathrm{Na}^{+}$efflux [162]. SGK1 co-localizes with the $\mathrm{Na}^{+} / \mathrm{K}^{+}$-ATPase in renal epithelial cells [162]. In Xenopus laevis oocytes, SGK1 increased the activity of both endogenous and exogenous $\mathrm{Na}^{+} / \mathrm{K}^{+}$-ATPase $[48,97,163-166]$. In A6 cells derived from the Xenopus laevis distal tubule, SGK1 expression increases $\mathrm{Na}^{+} / \mathrm{K}^{+}$-ATPase activity, independent of changes in abundance at the plasma membrane or protein expression [162]. Constitutively active mutant of SGK1 (SGK1 $1_{\text {S425D }}$ ) stimulates existing $\mathrm{Na}^{+}$pumps in the basolateral plasma membrane for the $\mathrm{Na}^{+}$exiting [162], which would maintain the chemical driving force for $\mathrm{Na}^{+}$entry through $\mathrm{ENaC}$ [162]. In addition, the stimulatory effect of SGK1 on $\mathrm{Na}^{+} / \mathrm{K}^{+}$-ATPase is mimicked by the isoforms SGK2 and SGK3 in Xenopus laevis oocytes [167].

\subsection{Type A Natriuretic Peptide Receptor (NPR-A)}

The human isoform of SGK1 has been identified as a cell volume-regulated gene that is modulated transcriptionally by cell swelling and shrinkage $[3,168,169]$. Accordingly, SGK1 has been shown to be involved in the extracellular tonicity-dependent stimulation of the NPR-A gene promoter in rat inner medullary collecting duct (IMCD) cells via the p38 mitogen-activated protein kinase (MAPK)-dependent pathway [170]. Beyond that, hypertonicity induces the expression of tonicity-responsive enhancer binding protein/nuclear factor of activated T cells 5 (TonEBP/NFAT5), which accounts for the osmosensitivity of the SGK1 gene promoter [61]. In turn, SGK1 does indeed serve as a key mediator in the osmotic induction of NPR-A gene expression [61].

Taken together, SGK1 acts as a key intracellular signal that regulates the activities of ENaC, Nav1.5, NHE1 and NHE3, NCC, NKCC2, $\mathrm{Na}^{+} / \mathrm{K}^{+}$-ATPase, and NPR-A, thus contributing to $\mathrm{Na}^{+}$ homeostasis (Table 2). 
Table 2. SGK1-dependent mediators of $\mathrm{Na}^{+}$channels and transporters. *

\begin{tabular}{|c|c|c|c|c|}
\hline $\mathrm{Na}^{+}$Channels and Transporters & Mediators & SGK1 Regulation & Possible Mechanism & Reference \\
\hline \multirow[t]{5}{*}{$\mathrm{ENaC}$} & Nedd4-2/14-3-3 protein & $\begin{array}{l}\text { SGK1 phosphorylates and sequesters the negative } \\
\text { regulator Nedd4-2. Meanwhile, SGK1 recruits } \\
\text { 14-3-3 to stabilize Nedd4-2 interacting with 14-3-3 }\end{array}$ & $\begin{array}{l}\text { Nedd4- } 2 \text { interacts with } \mathrm{ENaC} \text { to induce } \\
\text { ubiquitination and retrieval of } \mathrm{ENaC} \text { channel; } \\
\text { whereas } 14-3-3 \text { binds to Nedd4-2 and inhibits the } \\
\text { interaction between Nedd4- } 2 \text { and } \mathrm{ENaC}\end{array}$ & {$[102,171]$} \\
\hline & iNOS & SGK1 phosphorylates iNOS & NO reduces the open probability of $\mathrm{ENaC}$ & [172] \\
\hline & AF9-Dot1a complex & $\begin{array}{l}\text { SGK1 phosphorylates AF9 and promotes Dot1a to } \\
\text { dissociate from the } \alpha \text {-ENaC promoter }\end{array}$ & $\begin{array}{l}\text { AF9-Dot1a complex facilitates Dot1a to } \\
\text { hypermethylate Lys79 of histone } \mathrm{H} 3 \text { and } \\
\text { suppress } \alpha \text {-ENaC transcription }\end{array}$ & [126] \\
\hline & WNK4 & SGK1 phosphorylates WNK4 & WNK4 inhibits ENaC activity & [118] \\
\hline & NDRG2 & SGK1 phosphorylates NDRG2 protein & $\begin{array}{l}\text { NDRG2 stimulates ENaC activity and } \\
\text { increase its surface expression }\end{array}$ & [33] \\
\hline Nav 1.5 & Nedd4-2 & SGK1 phosphorylates and inactivates Nedd4-2 & Nedd4-2 inhibits Nav1.5 activity & [135] \\
\hline NHE1 & 14-3-3 protein & SGK1 recruits $14-3-3$ binding & $\begin{array}{l}\text { 14-3-3 facilitates SGK1 to phosphorylate } \\
\text { and stimulate NHE1 }\end{array}$ & [143] \\
\hline NHE3 & NHERF2 & SGK1 interacts with NHERF2 & $\begin{array}{l}\text { NHERF2 tethers SGK1 and NHE3 to facilitate } \\
\text { the phosphorylation of NHE3 }\end{array}$ & [141] \\
\hline NCC & Nedd4-2 & $\begin{array}{l}\text { SGK1 Phosphorylates Nedd4-2 and abrogates } \\
\text { Nedd4-2-mediated inhibition }\end{array}$ & $\begin{array}{l}\text { Nedd4-2 is co-located with NCC and involved } \\
\text { in the ubiquitylation of NCC transporter }\end{array}$ & [156] \\
\hline
\end{tabular}

* See text for abbreviations. 


\section{Physiological Role of SGK1 in $\mathrm{Na}^{+}$Transport}

\subsection{SGK1-Dependent Renal $\mathrm{Na}^{+}$Reabsorption}

The kidneys play a pivotal role in the maintenance of $\mathrm{Na}^{+}$homeostasis $[62,173]$. Urinary $\mathrm{Na}^{+}$ reabsorption is regulated tightly to maintain a constant extracellular volume as limiting extrarenal $\mathrm{Na}^{+}$ loss during dietary $\mathrm{Na}^{+}$restriction [47]. The final adjustment to renal $\mathrm{Na}^{+}$balance is achieved in the ASDN: i.e., the distal convoluted tubule (DCT), the connecting tubule (CNT), the cortical collecting duct (CCD) and the medullary collecting duct (MCD) $[120,163]$. Aldosterone and vasopressin play major roles in regulating $\mathrm{Na}^{+}$flux in epithelial tissues in these segments $[85,174,175]$. This effect is accomplished by the coordinated action of $\mathrm{Na}^{+}$entry into the epithelial cells via $\mathrm{ENaC}$ channel on the apical membrane, as well as $\mathrm{Na}^{+}$exit through the $\mathrm{Na}^{+} / \mathrm{K}^{+}$-ATPase pump on the basolateral plasma membrane $[47,176]$.

As illustrated above, SGK1 regulates $\mathrm{ENaC}[62,85,173]$ in the apical membrane and the $\mathrm{Na}^{+} / \mathrm{K}^{+}$-ATPase in the basolateral membrane, thereby coordinating $\mathrm{Na}^{+}$transport at both sides of epithelial cells [177]. In early distal tubules, the chlorothiazide-sensitive NCC mediates $\mathrm{Na}^{+}$ uptake [178,179]. SGK1 phosphorylates Nedd4-2 and WNK4, blocking their inhibitory effects on NCC [180]. In addition to stimulating $\mathrm{Na}^{+}$uptake in the ASDN, SGK1 participates in $\mathrm{Na}^{+}$transport in other renal segments. In rats and mice on a standard $\mathrm{NaCl}$ diet, expression of $S g k 1$ mRNA was detected in the glomeruli, proximal tubules [181], ASDN, and particularly strongly, in the IMCD [32,182]. SGK1 protein is localized to the TAL and ASDN [163], whereas very low protein expression was detected under basal conditions in the glomeruli, proximal tubule or MCD, including the papilla in rat kidneys [181,182]. Therefore, apart from ENaC, SGK1 increases $\mathrm{Na}^{+}$reabsorption via various transporters: NHE3 in the proximal tubule (PT) $[136,183,184]$; NKCC2 in the loop of Henle of TAL; as well as the $\mathrm{Na}^{+}$pump in different nephron segments [180].

The central role of SGK1 in the hormonal control of $\mathrm{Na}^{+}$handling is further illustrated by the observations in mice lacking $S g k 1$ [80,185-187]. Under a normal-salt diet, the phenotype of the $S g k 1^{-/-}$mouse was virtually identical to that of its wildtype littermates $\left(S g k 1^{+/+}\right)[80,178,186,188]$. These $S g k 1^{-/-}$mice showed no obvious defect in water and $\mathrm{Na}^{+}$excretion, and maintained normal apical membrane staining for $\alpha-\mathrm{ENaC}$ in the connecting tubule, except for higher circulating aldosterone levels, suggesting extracellular volume depletion $[188,189]$. However, when exposed to an $\mathrm{NaCl}$-deficient diet, the $S g k 1^{-1-}$ mice presented a dramatic urinary salt wasting phenotype: weight loss caused by increased urine production, decreased systolic and diastolic blood pressure, increased urinary $\mathrm{Na}^{+}$and $\mathrm{K}^{+}$excretion with unchanging plasma $\mathrm{Na}^{+}$and $\mathrm{K}^{+}$levels, and higher plasma aldosterone [80,188]. Wulff et al. [188] reported a weaker amiloride-sensitive transepithelial transport potential difference in isolated collecting ducts (CD) of $S g k 1^{-/-}$mice compared with $S g k 1^{+/+}$mice. In contrast, Fejes-Tóth et al. [80] reported increased amiloride-sensitive $\mathrm{Na}^{+}$currents with decreased $\gamma$-ENaC cleavage, as well as diminished NCC protein expression, in isolated collecting ducts of $S g k 1^{-/-}$ mice compared with the wildtype mice. Recently, Faresse et al. [186] generated doxycycline-inducible nephron tubule-specific $S g k 1$ knockout mice $\left(S g k 1^{P a x 8 / L C 1}\right)$, in which $S g k 1$ expression could be repressed within the kidney by treatment with doxycycline in the drinking water. The $S g k 1^{\text {Pax8 } / L C 1}$ mice also exhibit a large defect in $\mathrm{Na}^{+}$conservation when placed on a low- $\mathrm{Na}^{+}$diet [186]. Sgk1 ${ }^{\text {Pax8/LC1 }}$ mice have a decreased expression of the $\beta \gamma-\mathrm{ENaC}$ protein, without any change in $\gamma$-ENaC cleavage and $\alpha-E N a C$ mRNA expression [186]. Moreover, a significant reduction of NCC protein and no difference in mRNA levels has been observed in $S g k 1^{\text {Pax8/LC1 }}$ mice, along with decreased phosphorylation of Nedd4-2 on Ser-222 and Ser-328 by Sgk1. This finding suggests a potential SGK1-dependent regulation of NCC in renal $\mathrm{Na}^{+}$reabsorption [186].

\subsection{SGK1-Dependent Renal $\mathrm{Na}^{+}$Excretion}

Since its discovery in 1993, SGK1 was first identified in the response to cell volume alterations in a human hepatoma cell line $[168,169]$. Cell shrinkage leads to a rapid induction of SGK1 transcription 
in different cell lines $[61,92,168,190-196]$. Hypertonicity in the early phase leads to an acute increase in urinary sodium excretion $[61,170]$. In rat IMCD cells, SGK1 transcription is modulated by tonicity-responsive enhancer (TonE) binding protein (TonEBP/NFAT5) [61], which in turn activates NPR-A, resulting in sodium excretion $[61,170]$. As demonstrated in rat and mouse assays, increased extracellular osmolality does indeed increase $S g k 1$ and $N p r-A$ gene expressions concomitantly in the MCD. Furthermore, Chen et al. [61] reported that natriuretic peptide receptor 1 (Npr1) gene knockout mice $\left(\mathrm{Npr}^{-/-}\right)$failed to elicit changes in urinary $\mathrm{Na}^{+}$excretion when challenged with dehydration, despite elevated urinary osmolality and $S g k 1$ expression in the renal medulla. Collectively, these findings defined the contribution of the osmosensitive gene SGK1 to medullary sodium excretion (Figure 2), where it promotes the physiological response of the kidney to dehydration [61].
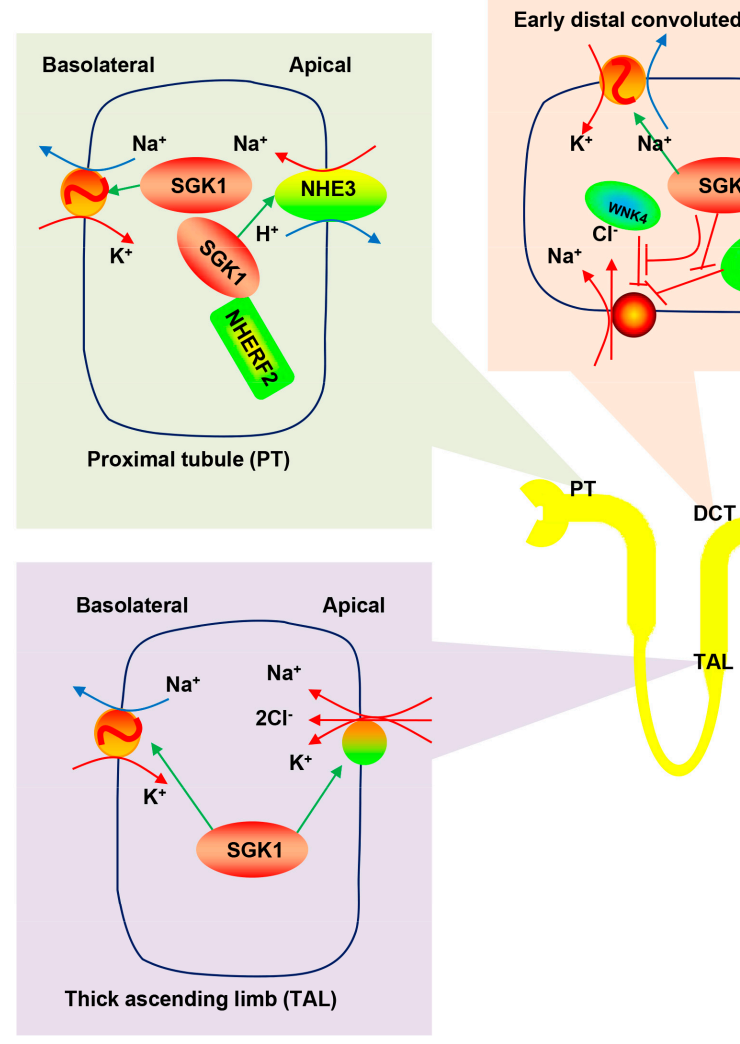
AL
Early distal convoluted tubule (DCT)

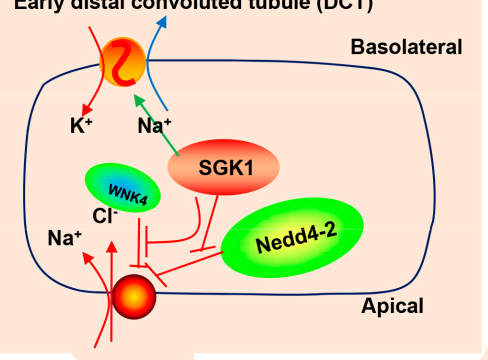

PT

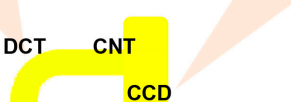

CCD

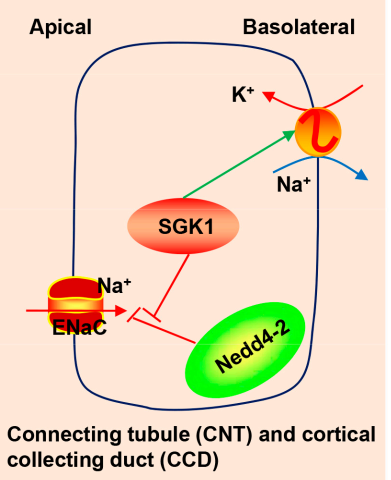

collecting duct (CCD)

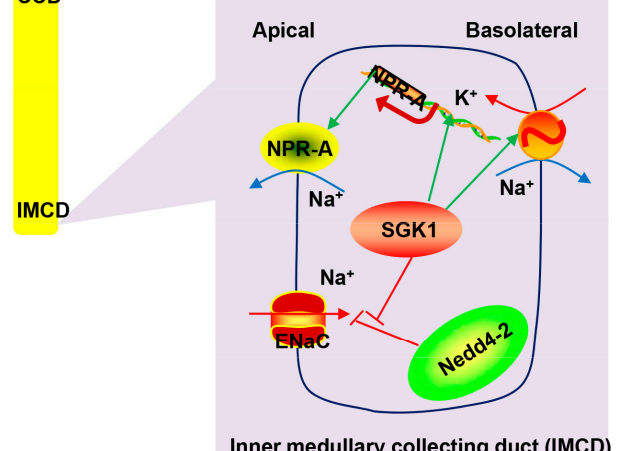

Inner medullary collecting duct (IMCD)

Figure 2. SGK1-dependent $\mathrm{Na}^{+}$reabsorption and excretion in the mammalian kidney tubule. SGK1 boosts $\mathrm{Na}^{+}$reabsorption via multiple transporters in different renal segments: NHE3 in the PT, NKCC2 in the loop of Henle TAL, sodium-chloride symporter (NCC) in the early distal convoluted tubule (DCT), ENaC primarily in the connecting tubule (CNT) and cortical collecting duct (CCD), as well as $\mathrm{Na}^{+}-\mathrm{K}^{+}$-ATPase pump throughout different nephron segments. SGK1 regulates $\mathrm{Na}^{+}$excretion in the medullary collecting duct (MCD) by activating NPR-A. SGK1, serum and glucocorticoid regulated kinase 1; NHE3, sodium hydrogen exchanger 3; NHERF2, NHE regulatory protein 2; WNK4, with no lysine kinase 4; Nedd4-2, neuronal precursor cell expressed developmentally down-regulated 4-2; $\mathrm{ENaC}$, epithelial sodium channel; NPR-A, type A natriuretic peptide receptor.

\subsection{Aldosterone-Induced Salt Appetite}

In addition to regulating renal $\mathrm{Na}^{+}$transport, SGK1 is thought to be involved in the regulation of aldosterone-induced salt adaptation and salt appetite [47,50,197-199]. When treated with deoxycorticosterone-acetate (DOCA) $/ 1 \% \mathrm{NaCl}, S g k 1^{+/+}$mice exhibited a pronounced increase in $\mathrm{Na}^{+}$intake and proteinuria compared with $S g k 1^{-/-}$mice [197]. The observation of pregnant mice further confirmed the role of SGK1 in the enhanced salt appetite as the preference for saline water was 
significantly stronger in $S g k 1^{+/+}$mice than in $S g k 1^{-/-}$mice [200]. Therefore, SGK1 were expected to participate in the increased salt uptake during pregnancy, contributing to the increase extracellular fluid volume, which favors hypertension of pregnancy [200].

Although the underlying mechanism remains to be exploited, Vallon et al. [197] have proposed that SGK1 might contribute to the stimulation of salt appetite in response to mineralocorticoid excess by upregulating the activity of $\mathrm{Na}^{+} / \mathrm{K}^{+}$-ATPase in the amygdala, an area implicated in the modulation of salt appetite. Fu et al. [199] have assumed that aldosterone activates SGK1, Nedd4-2 and ENaC in both kidney and brain. They suggested that SGK1 and ENaC were involved in aldosterone-induced salt appetite, as $\mathrm{ENaC}$ also mediates the gustatory salt sensing.

Thus, SGK1 appears to play a dual role in hormone-regulated $\mathrm{Na}^{+}$homeostasis, attenuating urinary salt output by regulating $\mathrm{ENaC}-$ mediated renal $\mathrm{Na}^{+}$reabsorption on the one side, and increasing salt intake through stimulating salt appetite on the other $[197,200]$.

Notably, the dual effects converge to expand the extracellular volume, which is supposed to favor salt-sensitive hypertension [201-206].

\subsection{SGK1-Dependent Intestinal Sodium Absorption}

Under basal conditions, SGK1 is expressed robustly in the distal colon, ileum and jejunum, which are beyond the aldosterone-responsive segments, suggesting a constitutive role in absorptive epithelia [207]. Consistently, ENaC, which is phosphorylated regulated by SGK1, plays a pivotal role in minimizing intestinal water and sodium losses in the distal colon [208]. Therefore, Dames et al. [208] showed that decreased SGK1 expression due to the suppression of interleukin-13 (IL-13) impaired epithelial sodium absorption via $\mathrm{ENaC}$.

Aldosterone-induced intestinal $\mathrm{Na}^{+}$absorption is also mediated by apical $\mathrm{Na}^{+}-\mathrm{H}^{+}$-exchangers (NHE2/3) and basolateral $\mathrm{Na}^{+} / \mathrm{K}^{+}$-ATPase [209]. SGK1 has been proposed to be part of this cascade [140]. Using human colonic Caco-2 and opossum kidney cells, Wang et al. [140] observed a biphasic activation of NHE3, which is responsible for the electrogenic $\mathrm{Na}^{+}$absorption in the intestinal epithelium. Furthermore, Musch et al. [210] demonstrated a potential role for SGK1 in the two phases of aldosterone-induced intestinal $\mathrm{Na}^{+}$absorption. The initial phase involves enhanced insertion of the $\alpha$-subunit of $\mathrm{Na}^{+} / \mathrm{K}^{+}$-ATPase through a PI3K-SGK1-dependent pathway and subsequently increased levels of apical membrane NHE3.The later activation is mainly concerned with elevated expression and activities of total NHE3 and $\mathrm{Na}^{+} / \mathrm{K}^{+}$-ATPase ( $\alpha$-subunit), both of which are regulated by SGK1 [210].

\subsection{SGK1-Dependent Lung Fluid Absorption}

SGK1 is expressed strongly in the lower respiratory tract. The SGK1-dependent regulation of $\mathrm{ENaC}$ in pulmonary epithelial cells plays a critical role in sodium/fluid homeostasis and in lung fluid clearance [90]. In this regard, several studies have reported increased SGK1 expression in prenatal lung segments $[7,211,212]$. Thus, decreased SGK1 expression could contribute to the inability to clear excessive lung fluid immediately after preterm birth $[213,214]$.

Using H441 human airway epithelial cells, Ismail et al. [91] showed that the activation of SGK1 by dexamethasone increases the surface expression of $\alpha-, \beta$ - and $\gamma$-ENaC, while the inhibition of SGK1 suppresses the phosphorylation of Nedd4- 2 and reduces the surface abundance of $\alpha$-ENaC, contributing to increased membrane $\mathrm{Na}^{+}$transport [91]. Furthermore, in the lipopolysaccharide (LPS)-induced acute lung injury (ALI), activation of SGK1 promotes both the total gene expression and the surface abundance of ENaC, leading to a protective effect in the case of LPS-induced ALI [74,82,94]. Therefore, SGK1 is essential to the induction and maintenance of controlled $\mathrm{Na}^{+}$absorption in the respiratory system, and is involved in the hormonal management of respiratory distress and pulmonary edema, which are clinical manifestations of abnormal pulmonary $\mathrm{Na}^{+}$absorption [91]. 


\subsection{SGK1-Dependent Peripheral $\mathrm{Na}^{+}$Transport}

SGK1 is co-expressed with ENaC in the human ocular ciliary epithelium and basal cells of corneal endothelium $[74,82,94]$. The activation of $\mathrm{ENaC}, \mathrm{NKCC} 2$ and $\mathrm{Na}^{+} / \mathrm{K}^{+}$-ATPase induced by SGK1 could contribute to sodium transport in the human ocular ciliary epithelium and corneal endothelium, and further account for corneal transparency $[22,23]$.

In the epithelium of the human middle ear, $\mathrm{ENaC}$-mediated sodium transport is upregulated by dexamethasone via the glucocorticoid receptor (GR)-SGK1-Nedd4-2 pathway $[25,215]$. Zhong et al. [216] showed that SGK1 is expressed in various regions of guinea pig cochlea, being associated with the regulation of endolymph homeostasis by mediating passive entry of sodium into cells. Thus SGK1 could be involved in the therapeutic activity of glucocorticoids in the treatment of Meniere's disease, a debilitating condition that manifests endolymphatic hydrops, which might be associated with $\mathrm{Na}^{+}$hypoabsorption in the vestibular lumen $[25,215]$.

\section{Pathological Role of SGK1 in $\mathrm{Na}^{+}$Transport}

\subsection{Salt-Sensitive Hypertension}

Excessive renal $\mathrm{Na}^{+}$retention can increase the circulating volume which may contribute to the development of high blood pressure [189]. SGK1 participates in facilitating hormonal actions involved in stimulating salt intake and inhibiting renal sodium loss; thereby influencing the long term control of arterial blood pressure, thus contributing to the development of hypertension.

The daily salt intake seems to predispose certain individuals to develop salt-sensitive hypertension [201,217-219]. Sgk1 is believed to contribute to the preference for a high salt diet and be involved in hormone-induced salt adaptation [197,198]. In Dahl salt-sensitive (DS) rats, which show hypertension with a high salt diet, the renal expression of $S g k 1$ is elevated greatly [201]. Furthermore, in animals receiving a high-fat diet [202] or high fructose intake [203], in addition to high salt intake, increased blood pressure is only detected in $S g k 1^{+/+}$mice, but not in $S g k 1^{-/-}$mice. Following high-salt intake, Sgk1-mediated up-regulation of ENaC, as well as $\mathrm{Na}^{+} / \mathrm{K}^{+}$-ATPase, stimulates $\mathrm{Na}^{+}$transport in the cerebrospinal fluid and the brain, which would activate the renin-angiotensin system, leading to the release of ouabain-like compound (OLC) which in turn activates the renin-angiotensin system, thereby increasing blood pressure [220].

Renal salt retention is another culprit thought to be involved in the development of hypertension $[96,171,200,221]$. The renal re-absorption of $\mathrm{Na}^{+}$is critical to whole body $\mathrm{Na}^{+}$and water balance, and to the control of blood pressure [180,221]. This process, as discussed above, is accomplished partially via the mediation by SGK1. SGK1 enhances the activity of ENaC, NCC, NKCC2, and $\mathrm{Na}^{+} / \mathrm{K}^{+}$-ATPase, which in turn increase the $\mathrm{Na}^{+}$re-absorption $[189,222]$. In particular, in primary aldosteronism or Liddle's syndrome, SGK1 increases the activity of ENaC channels in response to aldosterone [223,224]. In addition, gene variants of these transporters and enzyme are also associated with increased blood pressure $[189,225]$.

In fact, some distinct variants of the SGK1 gene are indeed indicated in increased blood pressure [189]. Polymorphisms in intron 6 [I6CC] and exon 8 [E8CC/CT] are associated with moderately enhanced blood pressure in individuals carrying these variants [226-230]. These gene variants affect about $3 \%-5 \%$ of the Caucasian population $[226,227]$ and $11.6 \%$ of a healthy African population [231]. In a study of 421 hypertensive Caucasian participants, Rao et al. [217] determined that two single nucleotide polymorphisms (SNPs) of SGK1 (rs2758151 and rs9402571) were associated with effects upon blood pressure and plasma renin activity (PRA) as a result of dietary salt intake. The major allele homozygotes at either rs2758151 or rs9402571 were associated with high systolic blood pressure in response to a high salt diet and decreased PRA on a low salt diet [217]. Recently, Chu et al. [232] reported that a genetic polymorphism in SGK1 is significantly correlated with the blood pressure response to dietary sodium intervention: SNP rs9389154 was associated with systolic blood pressure (SBP), while SNPs (rs1763509 and rs9376026) were associated with diastolic blood pressure 
(DBP). SNP rs9376026 was significantly associated with both mean arterial pressure (MAP) and DBP, and SNP rs3813344 was significantly linked with SBP, DBP, and MAP. Accordingly, individuals with these genotypes would be prone to salt-sensitive hypertension $[217,232]$.

Moreover, Sgk1 appears to be critical for the fetal programming of hypertension [172,233,234]. A protein-deficient diet during pregnancy leads to increased blood pressure in the offspring of $S g k 1^{+/+}$ mothers mice $[233,234]$.

Taken together, dysregulation of SGK1 activity or certain specific gene variants of SGK1 could be involved in salt-sensitive hypertension $[233,234]$.

\subsection{Edema with Diabetes Mellitus}

Synthetic PPAR $\gamma$ agonists are used to improve insulin sensitivity in patients with diabetes mellitus; however, their use is limited by fluid retention [184,235-238]. This $\mathrm{Na}^{+}$retention in nephrons may contribute to the development of edema and promote secondary hypertension in patients with type 2 diabetes mellitus, as a side effect of PPAR $\gamma$ treatment [62]. PPAR $\gamma$ agonists promote the activation of SGK1, the phosphorylation of Nedd4-2 and abolish ubiquitination and internalization of ENaC, leading to sodium and fluid retention [62]. Moreover, PPAR $\gamma$ stimulates $\mathrm{Na}^{+}$transport in the distal tubular epithelia and proximal tubule cells via SGK1-dependent regulation of NHE3 $[184,237,239]$. Thus SGK1 contributes to the dysregulation of cellular $\mathrm{Na}^{+}$and water transport in diabetes mellitus [184].

\subsection{Cardiac Dysfunction}

Dysregulation of $\mathrm{Na}^{+}$homeostasis has been implicated in cardiac rhythm disorders as well as adverse ventricular remodeling $[132,134]$. SGK1 plays a pivotal role in early cardiac angiogenesis and vascular remodeling $[135,240,241]$. Chronic SGK1 activation in the heart increases mortality caused by cardiac arrhythmias $[134,144]$. This effect is paralleled by SGK1-dependent stimulation of the cardiac sodium channel Nav1.5 [134], the major influx channel responsible for the initiation of the cardiac action potential [132]. The SGK1-dependent upregulation of Nav1.5 alters sodium flux, leading to arrhythmia and cardiomyopathy [132,134,242].

Recent data suggested that the $\mathrm{Na}^{+} / \mathrm{H}^{+}$exchanger NHE1, a target of SGK1, is involved in cardiac pathophysiology $[143,144]$. By increasing $\mathrm{Na}^{+}$entry and subsequently decreasing the chemical $\mathrm{Na}^{+}$ gradient through a NHE1-mediated pathway, SGK1 contributes to myocardial remodeling, cardiac hypertrophy and progression to heart failure [78,134,143,144].

\subsection{Implantation Failure}

SGK1 has been detected in the human endometrium [243-247] and placenta [245-248]. Using a cDNA microarray, a previous study identified SGK1 as a gene aberrantly expressed specifically in luminal epithelia during the midsecretory receptive phase of the cycle in infertile women [243]. In line with this, Salker et al. [246] confirmed that transcription of SGK1 was higher in the uterine luminal epithelia of infertile women compared with fertile controls. They further demonstrated a transient down-regulation of $S g k 1$ transcription in the mouse luminal epithelium during the window of endometrial receptivity $[245,246,248]$. Moreover, the expression of $\mathrm{ENaC}$ was upregulated, accompanied by the downregulation of Nedd4-2 in the $S g k 1^{-/-}$mice $[245,246,248]$. In this respect, SGK1 expression and functional activation account for a successful implantation, by modulating ENaC activities and consequent fluid absorption before engraftment [248].

\section{Conclusions and Perspectives}

SGK1 is a prominent regulator of multiple $\mathrm{Na}^{+}$channels, pumps and carriers, and thus contributes to the regulation of epithelial $\mathrm{Na}^{+}$transport, cell volume and sodium homeostasis. This kinase is not expected to possess housekeeping functions, judging by the mild phenotype shown in both ubiquitous gene knockout and inducible tissue-specific Sgk1 knockout mice [50,80,186,188,249]. By contrast, the gain of function of SGK1 is seemingly crucial for the pathophysiology of a wide variety of 
disorders [50,249]. Accordingly, SGK1 is thought to be involved in the formation of fibrosis which is characterized by dysregulated $\mathrm{Na}^{+}$transport in several tissues $[96,250]$. Increased SGK1 expression has been implicated in various fibrotic diseases, such as cystic fibrosis [96,251], renal fibrosis and albuminuria [250], diabetic nephropathy [250], glomerulonephritis [250], Crohn's disease, fibrosing pancreatitis, and liver cirrhosis $[48,50,249]$. Additionally, as an osmosis-sensitive gene, SGK1 might play a role in apoptosis, where cell shrinkage serves as a signal in programmed cell death or apoptosis [252]. In fact, downstream targets of SGK1, such as $\mathrm{Na}^{+} / \mathrm{K}^{+}$-ATPase and NHE1, are involved in cell apoptosis [252]. Recently, SGK1 has been proposed as a potential target of sodium intervention in immune cells $[253,254]$. $\mathrm{NaCl}$ affects the regulatory balance of type 1 helper $\mathrm{T}$ cell $\left(\mathrm{T}_{\mathrm{H}} 1\right), \mathrm{T}_{\mathrm{H}} 2, \mathrm{~T}_{\mathrm{H}} 17$ and regulatory $\mathrm{T}$ cells $\left(\mathrm{T}_{\text {reg }}\right.$ cells) in an SGK1-dependent manner [253,254]. In this regard, more studies are needed to determine whether SGK1 is a major driver or just a passenger in the pathophysiology of various disorders characterized by dysregulated sodium transport.

Acknowledgments: This work was supported by grants from the National Basic Research Program of China (no. 2014CB943302; no. 2012CB944901); the National Natural Science Program of China (no. 81571500; no. 81370760); Natural Science Program of Zhejiang Province, China (no. Y2100822); Zhejiang Provincial Natural Science Foundation of China (no. LZ13H040001; no. LZ15H040001); Medical Scientific Research Program of Zhejiang Province (no. 2014KYA269; no. 2016KYA120); Health Science and Technology Program of Hangzhou (no. 2014A54); and Traditional Chinese medicine Program of Zhejiang Province (no. 2015ZA159).

Author Contributions: Yiyun Lou wrote and revised the manuscript; Liya Wang and Yiyun Lou were involved in drafting the figures; Fan Zhang, Yuqin Luo and Shisi Huang provided critical suggestions to the manuscript; Fan Jin critically reviewed and revised the manuscript. All authors read and approved the final manuscript.

Conflicts of Interest: The authors declare no conflict interest.

\section{References}

1. Webster, M.K.; Goya, L.; Firestone, G.L. Immediate-early transcriptional regulation and rapid mRNA turnover of a putative serine/threonine protein kinase. J. Biol. Chem. 1993, 268, 11482-11485. [PubMed]

2. Webster, M.K.; Goya, L.; Ge, Y.; Maiyar, A.C.; Firestone, G.L. Characterization of SGK, a novel member of the serine/threonine protein kinase gene family which is transcriptionally induced by glucocorticoids and serum. Mol. Cell. Biol. 1993, 13, 2031-2040. [CrossRef] [PubMed]

3. Waldegger, S.; Barth, P.; Raber, G.; Lang, F. Cloning and characterization of a putative human serine/threonine protein kinase transcriptionally modified during anisotonic and isotonic alterations of cell volume. Proc. Natl. Acad. Sci. USA 1997, 94, 4440-4445. [CrossRef] [PubMed]

4. Pearce, L.R.; Komander, D.; Alessi, D.R. The nuts and bolts of AGC protein kinases. Nat. Rev. Mol. Cell Biol. 2010, 11, 9-22. [CrossRef] [PubMed]

5. Wesch, D.; Miranda, P.; Afonso-Oramas, D.; Althaus, M.; Castro-Hernandez, J.; Dominguez, J.; Morty, R.E.; Clauss, W.; Gonzalez-Hernandez, T.; de la Rosa, D.A.; et al. The neuronal-specific SGK1.1 kinase regulates delta-epithelial $\mathrm{Na}^{+}$channel independently of PY motifs and couples it to phospholipase C signaling. Am. J. Physiol. Cell Physiol. 2010, 299, C779-C790. [CrossRef] [PubMed]

6. Andres-Mateos, E.; Brinkmeier, H.; Burks, T.N.; Mejias, R.; Files, D.C.; Steinberger, M.; Soleimani, A.; Marx, R.; Simmers, J.L.; Lin, B.; et al. Activation of serum/glucocorticoid-induced kinase 1 (SGK1) is important to maintain skeletal muscle homeostasis and prevent atrophy. EMBO Mol. Med. 2013, 5, 80-91. [CrossRef] [PubMed]

7. Keller-Wood, M.; Von Reitzenstein, M.; McCartney, J. Is the fetal lung a mineralocorticoid receptor target organ? Induction of cortisol-regulated genes in the ovine fetal lung, kidney and small intestine. Neonatology 2009, 95, 47-60. [CrossRef] [PubMed]

8. Notch, E.G.; Shaw, J.R.; Coutermarsh, B.A.; Dzioba, M.; Stanton, B.A. Morpholino gene knockdown in adult Fundulus heteroclitus: Role of SGK1 in seawater acclimation. PLoS ONE 2011, 6, e29462. [CrossRef] [PubMed]

9. Shaw, J.R.; Bomberger, J.M.; VanderHeide, J.; LaCasse, T.; Stanton, S.; Coutermarsh, B.; Barnaby, R.; Stanton, B.A. Arsenic inhibits SGK1 activation of CFTR $\mathrm{Cl}^{-}$channels in the gill of killifish, Fundulus heteroclitus. Aquat. Toxicol. 2010, 98, 157-164. [CrossRef] [PubMed]

10. Roelants, F.M.; Baltz, A.G.; Trott, A.E.; Fereres, S.; Thorner, J. A protein kinase network regulates the function of aminophospholipid flippases. Proc. Natl. Acad. Sci. USA 2010, 107, 34-39. [CrossRef] [PubMed] 
11. Jacquier, N.; Schneiter, R. Ypk1, the yeast orthologue of the human serum- and glucocorticoid-induced kinase, is required for efficient uptake of fatty acids. J. Cell Sci. 2010, 123, 2218-2227. [CrossRef] [PubMed]

12. Kolb, A.R.; Buck, T.M.; Brodsky, J.L. Saccharomyces cerivisiae as a model system for kidney disease: What can yeast tell us about renal function? Am. J. Physiol. Ren. Physiol. 2011, 301, F1-F11. [CrossRef] [PubMed]

13. Colabardini, A.C.; Brown, N.A.; Savoldi, M.; Goldman, M.H.S.; Goldman, G.H. Functional characterization of Aspergillus nidulans ypkA, a homologue of the mammalian kinase SGK. PLoS ONE 2013. [CrossRef] [PubMed]

14. Niles, B.J.; Powers, T. Plasma membrane proteins Slm1 and Slm2 mediate activation of the AGC kinase Ypk1 by TORC2 and sphingolipids in S. cerevisiae. Cell Cycle 2012, 11, 3745-3749. [CrossRef] [PubMed]

15. Bakre, A.; Andersen, L.E.; Meliopoulos, V.; Coleman, K.; Yan, X.; Brooks, P.; Crabtree, J.; Tompkins, S.M.; Tripp, R.A. Identification of host kinase genes required for influenza virus replication and the regulatory role of microRNAs. PLoS ONE 2013, 8, e66796. [CrossRef] [PubMed]

16. Wang, H.W.; Huang, B.S.; Chen, A.; Ahmad, M.; White, R.A.; Leenen, F.H.H. Role of brain aldosterone and mineralocorticoid receptors in aldosterone-salt hypertension in rats. Neuroscience 2016, 314, 90-105. [CrossRef] [PubMed]

17. Gao, P.; Limpens, J.H.; Spijker, S.; Vanderschuren, L.J.; Voorn, P. Stable immediate early gene expression patterns in medial prefrontal cortex and striatum after long-term cocaine self-administration. Addict. Biol. 2015. [CrossRef] [PubMed]

18. Lin, T.-B.; Hsieh, M.-C.; Lai, C.-Y.; Cheng, J.-K.; Chau, Y.-P.; Ruan, T.; Chen, G.-D.; Peng, H.-Y. Modulation of nerve injury-induced HDAC4 cytoplasmic retention contributes to neuropathic pain in rats. Anesthesiology 2015, 123, 199-212. [CrossRef] [PubMed]

19. Chen, L.; Wei, T.Q.; Wang, Y.; Zhang, J.; Li, H.; Wang, K.J. Simulated bladder pressure stimulates human bladder smooth muscle cell proliferation via the PI3K/SGK1 signaling pathway. J. Urol. 2012, 188, 661-667. [CrossRef] [PubMed]

20. Sahin, P.; McCaig, C.; Jeevahan, J.; Murray, J.T.; Hainsworth, A.H. The cell survival kinase SGK1 and its targets FOXO3a and NDRG1 in aged human brain. Neuropathol. Appl. Neurobiol. 2013, 39, 623-633. [CrossRef] [PubMed]

21. Zhang, T.; Fang, S.; Wan, C.; Kong, Q.; Wang, G.; Wang, S.; Zhang, H.; Zou, H.; Sun, B.; Sun, W.; et al. Excess salt exacerbates blood-brain barrier disruption via a p38/MAPK/SGK1-dependent pathway in permanent cerebral ischemia. Sci. Rep. 2015, 5, 16548. [CrossRef] [PubMed]

22. Rauz, S.; Walker, E.A.; Hughes, S.V.; Coca-Prados, M.; Hewison, M.; Murray, P.L.; Stewart, P.M. Serum- and glucocorticoid-regulated kinase isoform-1 and epithelial sodium channel subunits in human ocular ciliary epithelium. Investig. Ophthalmol. Vis. Sci. 2003, 44, 1643-1651. [CrossRef]

23. Rauz, S.; Walker, E.A.; Murray, P.I.; Stewart, P.M. Expression and distribution of the serum and glucocorticoid regulated kinase and the epithelial sodium channel subunits in the human cornea. Exp. Eye Res. 2003, 77, 101-108. [CrossRef]

24. Wang, Y.; Lin, C.; He, Y.; Li, A.; Ni, W.; Sun, S.; Gu, X.; Li, J.; Li, H. miR-27a promotes apoptosis of cochlear sensory epithelium in Cx26 knockout mice. Front. Biosci. 2016, 21, 364-373.

25. Kim, B.G.; Kim, J.Y.; Kim, M.; Kim, C.H.; Choi, J.Y.; Kim, S.H. Gene regulation by glucocorticoid in $\mathrm{ENaC}-$ mediated $\mathrm{Na}^{+}$transport by middle ear epithelial cells. Laryngoscope 2013. [CrossRef] [PubMed]

26. Lee, E.; Lein, E.S.; Firestone, G.L. Tissue-specific expression of the transcriptionally regulated serum and glucocorticoid-inducible protein kinase (Sgk) during mouse embryogenesis. Mech. Dev. 2001, 103, 177-181. [CrossRef]

27. Yu, X.B.; Lin, Q.; Qin, X.; Ruan, Z.; Zhou, J.H.; Lin, Z.F.; Su, Y.J.; Jian, Z. Serum and glucocorticoid kinase 1 promoted the growth and migration of non-small cell lung cancer cells. Gene 2016, 576, 339-346.

28. Waldegger, S.; Klingel, K.; Barth, P.; Sauter, M.; Rfer, M.L.; Kandolf, R.; Lang, F. $h$-sgk serine-threonine protein kinase gene as transcriptional target of transforming growth factor $\beta$ in human intestine. Gastroenterology 1999, 116, 1081-1088. [CrossRef]

29. Kobayashi, T.; Deak, M.; Morrice, N.; Cohen, P. Characterization of the structure and regulation of two novel isoforms of serum- and glucocorticoid-induced protein kinase. Biochem. J. 1999, 344, 189-197. [CrossRef] [PubMed] 
30. Klingel, K.; Warntges, S.; Bock, J.; Wagner, C.A.; Sauter, M.; Waldegger, S.; Kandolf, R.; Lang, F. Expression of cell volume-regulated kinase h-sgk in pancreatic tissue. Am. J. Physiol. Gastrointest. Liver Physiol. 2000, 279, G998-G1002. [PubMed]

31. Yaylaoglu, M.B.; Agbemafle, B.M.; Oesterreicher, T.J.; Finegold, M.J.; Thaller, C.; Henning, S.J. Diverse patterns of cell-specific gene expression in response to glucocorticoid in the developing small intestine. Am. J. Physiol. Gastrointest. Liver Physiol. 2006, 291, G1041-G1050. [CrossRef] [PubMed]

32. Hou, J.H.; Speirs, H.J.L.; Seckl, J.R.; Brown, R.W. Sgk1 gene expression in kidney and its regulation by aldosterone: Spatio-temporal heterogeneity and quantitative analysis. J. Am. Soc. Nephrol. 2002, 13, 1190-1198. [CrossRef] [PubMed]

33. Murray, J.T.; Campbell, D.G.; Morrice, N.; Auld, G.C.; Shpiro, N.; Marquez, R.; Peggie, M.; Bain, J.; Bloomberg, G.B.; Grahammer, F.; et al. Exploitation of KESTREL to identify NDRG family members as physiological substrates for SGK1 and GSK3. Biochem. J. 2004, 384, 477-488. [CrossRef] [PubMed]

34. Li, P.; Pan, F.; Hao, Y.; Feng, W.; Song, H.; Zhu, D. SGK1 is regulated by metabolic-related factors in 3T3-L1 adipocytes and overexpressed in the adipose tissue of subjects with obesity and diabetes. Diabetes Res. Clin. Pract. 2013, 102, 35-42. [CrossRef] [PubMed]

35. Di Pietro, N.; Panel, V.; Hayes, S.; Bagattin, A.; Meruvu, S.; Pandolfi, A.; Hugendubler, L.; Fejes-Toth, G.; Naray-Fejes-Toth, A.; Mueller, E. Serum- and glucocorticoid-inducible kinase 1 (SGK1) regulates adipocyte differentiation via forkhead Box O1. Mol. Endocrinol. 2010, 24, 370-380. [CrossRef] [PubMed]

36. Borst, O.; Schmidt, E.M.; Munzer, P.; Schonberger, T.; Towhid, S.T.; Elvers, M.; Leibrock, C.; Schmid, E.; Eylenstein, A.; Kuhl, D.; et al. The serum- and glucocorticoid-inducible kinase 1 (SGK1) influences platelet calcium signaling and function by regulation of Orai1 expression in megakaryocytes. Blood 2012, 119, 251-261. [CrossRef] [PubMed]

37. Pelzl, L.; Fakhri, H.; Umbach, A.T.; Gawaz, M.; Paulmichl, M.; Lang, F. Sgk1 sensitive pendrin expression in murine platelets. Cell. Physiol. Biochem. 2013, 32, 210-220. [CrossRef] [PubMed]

38. Bhavsar, S.K.; Merches, K.; Bobbala, D.; Lang, F. AKT/SGK-sensitive phosphorylation of GSK3 in the regulation of L-selectin and perforin expression as well as activation induced cell death of T-lymphocytes. Biochem. Biophys. Res. Commun. 2012, 425, 6-12. [CrossRef] [PubMed]

39. Schmid, E.; Xuan, N.T.; Zahir, N.; Russo, A.; Yang, W.; Kuhl, D.; Faggio, C.; Shumilina, E.; Lang, F. Serumand glucocorticoid-inducible kinase 1 sensitive NF-kB signaling in dendritic cells. Cell. Physiol. Biochem. 2014, 34, 943-954. [CrossRef] [PubMed]

40. Sun, J.-Y.; Li, C.; Shen, Z.-X.; Zhang, W.-C.; Ai, T.-J.; Du, L.-J.; Zhang, Y.-Y.; Yao, G.-F.; Liu, Y.; Sun, S.; et al. Mineralocorticoid receptor deficiency in macrophages inhibits neointimal hyperplasia and suppresses macrophage inflammation through SGK1-AP1/NF-kB pathways. Arterioscler. Thromb. Vasc. Biol. 2016, 36, 874-885. [CrossRef] [PubMed]

41. Schmid, E.; Gu, S.C.; Yang, W.T.; Munzer, P.; Schaller, M.; Lang, F.; Stournaras, C.; Shumilina, E. Serumand glucocorticoid-inducible kinase SGK1 regulates reorganization of actin cytoskeleton in mast cells upon degranulation. Am. J. Physiol. Cell Physiol. 2013, 304, C49-C55. [CrossRef] [PubMed]

42. Alliston, T.N.; Gonzalez-Robayna, I.J.; Buse, P.; Firestone, G.L.; Richards, J.S. Expression and localization of serum/glucocorticoid-induced kinase in the rat ovary: Relation to follicular growth and differentiation. Endocrinology 2000, 141, 385-395. [CrossRef] [PubMed]

43. Vadnais, M.L.; Aghajanian, H.K.; Lin, A.; Gerton, G.L. Signaling in sperm: Toward a molecular understanding of the acquisition of sperm motility in the mouse epididymis. Biol. Reprod. 2013, 89, 127. [CrossRef] [PubMed]

44. Gerovska, D.; Arauzo-Bravo, M.J. Does mouse embryo primordial germ cell activation start before implantation as suggested by single-cell transcriptomics dynamics? Mol. Hum. Reprod. 2016. [CrossRef] [PubMed]

45. Yang, L.; Yu, W.; Yan, W.L.; Peng, L.G. 116 Expression of insulin-like growth factor receptor (IGF2R), leptin receptor (LEPR) and serum- and glucocorticoid-regulated kinase 1 (SGK1) mRNA in human and bovine pregnancies. Reprod. Fertil. Dev. 2012, 25, 205. [CrossRef]

46. Driver, P.M.; Rauz, S.; Walker, E.A.; Hewison, M.; Kilby, M.D.; Stewart, P.M. Characterization of human trophoblast as a mineralocorticoid target tissue. Mol. Hum. Reprod. 2003, 9, 793-798. [CrossRef] [PubMed]

47. Loffing, J.; Flores, S.Y.; Staub, O. Sgk kinases and their role in epithelial transport. Annu. Rev. Physiol. 2006, 68, 461-490. [CrossRef] [PubMed] 
48. Lang, F.; Bohmer, C.; Palmada, M.; Seebohm, G.; Strutz-Seebohm, N.; Vallon, V. (Patho)physiological significance of the serum- and glucocorticoid-inducible kinase isoforms. Physiol. Rev. 2006, 86, 1151-1178. [CrossRef] [PubMed]

49. Zhao, B.; Lehr, R.; Smallwood, A.M.; Ho, T.F.; Maley, K.; Randall, T.; Head, M.S.; Koretke, K.K.; Schnackenberg, C.G. Crystal structure of the kinase domain of serum and glucocorticoid-regulated kinase 1 in complex with AMP-PNP. Protein Sci. 2007, 16, 2761-2769. [CrossRef] [PubMed]

50. Lang, F.; Voelkl, J. Therapeutic potential of serum and glucocorticoid inducible kinase inhibition. Expert Opin. Investig. Drugs 2013, 22, 701-714. [CrossRef] [PubMed]

51. Fairhall, E.A.; Charles, M.A.; Probert, P.M.; Wallace, K.; Gibb, J.; Ravindan, C.; Soloman, M.; Wright, M.C. Pancreatic B-13 Cell trans-differentiation to hepatocytes is dependent on epigenetic-regulated changes in gene expression. PLoS ONE 2016, 11, e0150959. [CrossRef] [PubMed]

52. Miyata, S.; Taniguchi, M.; Koyama, Y.; Shimizu, S.; Tanaka, T.; Yasuno, F.; Yamamoto, A.; Iida, H.; Kudo, T.; Katayama, T.; et al. Association between chronic stress-induced structural abnormalities in Ranvier nodes and reduced oligodendrocyte activity in major depression. Sci. Rep. 2016, 6, 23084. [CrossRef] [PubMed]

53. Chatterjee, S.; Schmidt, S.; Pouli, S.; Honisch, S.; Alkahtani, S.; Stournaras, C.; Lang, F. Membrane androgen receptor sensitive $\mathrm{Na}^{+} / \mathrm{H}^{+}$exchanger activity in prostate cancer cells. FEBS Lett. 2014, 588, 1571-1579. [CrossRef] [PubMed]

54. Wang, Y.; Zhou, D.; Chen, S. SGK3 is an androgen-inducible kinase promoting prostate cancer cell proliferation through activation of p70 S6 kinase and up-regulation of cyclin D1. Mol. Endocrinol. 2014, 28, 935-948. [CrossRef] [PubMed]

55. Liu, G.L.; Honisch, S.; Liu, G.X.; Schmidt, S.; Pantelakos, S.; Alkahtani, S.; Toulany, M.; Lang, F.; Stournaras, C. Inhibition of SGK1 enhances mAR-induced apoptosis in MCF-7 breast cancer cells. Cancer Biol. Ther. 2015, 16, 52-59. [CrossRef] [PubMed]

56. Dhiman, V.K.; Attwood, K.; Campbell, M.J.; Smiraglia, D.J. Hormone stimulation of androgen receptor mediates dynamic changes in DNA methylation patterns at regulatory elements. Oncotarget 2015, 6, 42575-42589. [PubMed]

57. Wehmeyer, L.; du Toit, A.; Lang, D.M.; Hapgood, J.P. Lipid raft- and protein kinase C-mediated synergism between glucocorticoid- and gonadotropin-releasing hormone signaling results in decreased cell proliferation. J. Biol. Chem. 2014, 289, 10235-10251. [CrossRef] [PubMed]

58. Toyonaga, J.; Tsuruya, K.; Ikeda, H.; Noguchi, H.; Yotsueda, H.; Fujisaki, K.; Hirakawa, M.; Taniguchi, M.; Masutani, K.; Iida, M. Spironolactone inhibits hyperglycemia-induced podocyte injury by attenuating ROS production. Nephrol. Dial. Transplant. 2011, 26, 2475-2484. [CrossRef] [PubMed]

59. Panchapakesan, U.; Pollock, C.; Saad, S. Renal epidermal growth factor receptor: Its role in sodium and water homeostasis in diabetic nephropathy. Clin. Exp. Pharmacol. Physiol. 2011, 38, 84-88. [CrossRef] [PubMed]

60. Lezak, M.; Gieryk, A.; Korostynski, M.; Piechota, M.; Wlazlo, E.; Przewlocki, R. Cell-type specific regulation of SGK1 isoforms by morphine and dexamethasone. Pharmacol. Rep. 2011, 63, 258.

61. Chen, S.C.; Grigsby, C.L.; Law, C.S.; Ni, X.P.; Nekrep, N.; Olsen, K.; Humphreys, M.H.; Gardner, D.G. Tonicity-dependent induction of $S g k 1$ expression has a potential role in dehydration-induced natriuresis in rodents. J. Clin. Investig. 2009, 119, 1647-1658. [CrossRef] [PubMed]

62. Chraibi, A.; Renauld, S. PPAR $\gamma$-induced stimulation of amiloride-sensitive sodium current in renal collecting duct principal cells is serum and insulin dependent. Cell. Physiol. Biochem. 2014, 33, 581-593. [CrossRef] [PubMed]

63. Schernthaner-Reiter, M.H.; Kiefer, F.; Zeyda, M.; Stulnig, T.M.; Luger, A.; Vila, G. Strong association of serum- and glucocorticoid-regulated kinase 1 with peripheral and adipose tissue inflammation in obesity. Int. J. Obes. 2015, 39, 1143-1150. [CrossRef] [PubMed]

64. Pastore, D.; Della-Morte, D.; Coppola, A.; Capuani, B.; Lombardo, M.F.; Pacifici, F.; Ferrelli, F.; Arriga, R.; Mammi, C.; Federici, M.; et al. SGK-1 protects kidney cells against apoptosis induced by ceramide and TNF- $\alpha$. Cell Death Dis. 2015, 6, e1890. [CrossRef] [PubMed]

65. Quadri, S.; Siragy, H.M. (Pro)renin receptor contributes to regulation of renal epithelial sodium channel. J. Hypertens. 2016, 34, 486-494. [CrossRef] [PubMed]

66. Scott, T.A.; Babayeva, O.; Banerjee, S.; Zhong, W.; Francis, S.C. SGK1 is modulated by resistin in vascular smooth muscle cells and in the aorta following diet-induced obesity. Obesity 2016, 24, 678-686. [CrossRef] [PubMed] 
67. Burgon, J.; Robertson, A.L.; Sadiku, P.; Wang, X.; Hooper-Greenhill, E.; Prince, L.R.; Walker, P.; Hoggett, E.E.; Ward, J.R.; Farrow, S.N.; et al. Serum and glucocorticoid-regulated kinase 1 regulates neutrophil clearance during inflammation resolution. J. Immunol. 2014, 192, 1796-1805. [CrossRef] [PubMed]

68. Zhang, B.; Umbach, A.T.; Chen, H.; Yan, J.; Fakhri, H.; Fajol, A.; Salker, M.S.; Spichtig, D.; Daryadel, A.; Wagner, C.A.; et al. Up-regulation of FGF23 release by aldosterone. Biochem. Biophys. Res. Commun. 2016, 470, 384-390. [CrossRef] [PubMed]

69. Lv, Y.; Gao, S.; Zhang, Y.; Wang, L.; Chen, X.; Wang, Y. miRNA and target gene expression in menstrual endometria and early pregnancy decidua. Eur. J. Obstet. Gynecol. Reprod. Biol. 2016, 197, 27-30. [CrossRef] [PubMed]

70. Liu, S.X.; Zhu, B.; Sun, Y.; Xie, X.F. miR-155 modulates the progression of neuropathic pain through targeting SGK3. Int. J. Clin. Exp. Pathol. 2015, 8, 14374-14382. [PubMed]

71. Kong, C.; Sun, L.; Zhang, M.; Ding, L.; Zhang, Q.; Cheng, X.; Diao, Z.; Yan, Q.; Zhang, H.; Fang, T.; et al. miR-133b reverses the hydrosalpinx-induced impairment of embryo attachment through down-regulation of SGK1. J. Clin. Endocrinol. Metab. 2016, 101, 1478-1489. [CrossRef] [PubMed]

72. Grahammer, F. Halting renal fibrosis: An unexpected role for mTORC2 signaling. Kidney Int. 2015, 88, 437-439. [CrossRef] [PubMed]

73. Salis, O.; Okuyucu, A.; Bedir, A.; Gor, U.; Kulcu, C.; Yenen, E.; Kilic, N. Antimetastatic effect of fluvastatin on breast and hepatocellular carcinoma cells in relation to SGK1 and NDRG1 genes. Tumour Biol. 2016, 37, 3017-3024. [CrossRef] [PubMed]

74. Zhu, T.; Zhang, W.; Wang, D.X. Insulin up-regulates epithelial sodium channel in LPS-induced acute lung injury model in rats by SGK1 activation. Injury 2012, 43, 1277-1283. [CrossRef] [PubMed]

75. Capobianco, E.; Fornes, D.; Linenberg, I.; Powell, T.L.; Jansson, T.; Jawerbaum, A. A novel rat model of gestational diabetes induced by intrauterine programming is associated with alterations in placental signaling and fetal overgrowth. Mol. Cell. Endocrinol. 2016, 422, 221-232. [CrossRef] [PubMed]

76. Ji, Y.M.; Zhou, X.F.; Zhang, J.; Zheng, X.; Li, S.B.; Wei, Z.Q.; Liu, T.; Cheng, D.L.; Liu, P.; Song, K.; et al. DEPTOR suppresses the progression of esophageal squamous cell carcinoma and predicts poor prognosis. Oncotarget 2016, 7, 14188-14198. [PubMed]

77. Fagerli, U.M.; Ullrich, K.; Stuhmer, T.; Holien, T.; Kochert, K.; Holt, R.U.; Bruland, O.; Chatterjee, M.; Nogai, H.; Lenz, G.; et al. Serum/glucocorticoid-regulated kinase 1 (SGK1) is a prominent target gene of the transcriptional response to cytokines in multiple myeloma and supports the growth of myeloma cells. Oncogene 2011, 30, 3198-3206. [CrossRef] [PubMed]

78. Binger, K.J.; Linker, R.A.; Muller, D.N.; Kleinewietfeld, M. Sodium chloride, SGK1, and Th17 activation. Pflug. Arch. Eur. J. Physiol. 2015, 467, 543-550. [CrossRef] [PubMed]

79. Chen, S.Y.; Bhargava, A.; Mastroberardino, L.; Meijer, O.C.; Wang, J.; Buse, P.; Firestone, G.L.; Verrey, F.; Pearce, D. Epithelial sodium channel regulated by aldosterone-induced protein SGK. Proc. Natl. Acad. Sci. USA 1999, 96, 2514-2519. [CrossRef] [PubMed]

80. Fejes-Toth, G.; Frindt, G.; Naray-Fejes-Toth, A.; Palmer, L.G. Epithelial $\mathrm{Na}^{+}$channel activation and processing in mice lacking SGK1. Am. J. Physiol. Ren. Physiol. 2008, 294, F1298-F1305. [CrossRef] [PubMed]

81. Bohmer, C.; Wagner, C.A.; Beck, S.; Moschen, I.; Melzig, J.; Werner, A.; Lin, J.T.; Lang, F.; Wehner, F. The shrinkage-activated $\mathrm{Na}^{+}$conductance of rat hepatocytes and its possible correlation to $\mathrm{rENaC}$. Cell. Physiol. Biochem. 2000, 10, 187-194. [CrossRef] [PubMed]

82. Qi, D.; He, J.; Wang, D.X.; Deng, W.; Zhao, Y.; Ye, Y.; Feng, L.H. 17 ß-Estradiol suppresses lipopolysaccharide-induced acute lung injury through PI3K/Akt/SGK1 mediated up-regulation of epithelial sodium channel (ENaC) in vivo and in vitro. Respir. Res. 2014, 15, 12. [CrossRef] [PubMed]

83. Wang, H.W.; Amin, M.S.; El-Shahat, E.; Huang, B.S.; Tuana, B.S.; Leenen, F.H.H. Effects of central sodium on epithelial sodium channels in rat brain. Am. J. Physiol. Regul. Integr. Comp. Physiol. 2010, 299, R222-R233. [CrossRef] [PubMed]

84. Rauh, R.; Dinudom, A.; Fotia, A.B.; Paulides, M.; Kumar, S.; Korbmacher, C.; Cook, D.I. Stimulation of the epithelial sodium channel $(\mathrm{ENaC})$ by the serum- and glucocorticoid-inducible kinase (Sgk) involves the PY motifs of the channel but is independent of sodium feedback inhibition. Pflug. Arch. Eur. J. Physiol. 2006, 452, 290-299. [CrossRef] [PubMed]

85. Jacobs, M.E.; Kathpalia, P.P.; Chen, Y.; Thomas, S.V.; Noonan, E.J.; Pao, A.C. SGK1 regulation by miR-466g in cortical collecting duct cells. Am. J. Physiol. Ren. Physiol. 2016, 310, F1251-F1257. [CrossRef] [PubMed] 
86. Helms, M.N.; Fejes-Toth, G.; Naray-Fejes-Toth, A. Hormone-regulated transepithelial $\mathrm{Na}^{+}$transport in mammalian CCD cells requires SGK1 expression. Am. J. Physiol. Ren. Physiol. 2003, 284, F480-F487. [CrossRef] [PubMed]

87. Wang, J.; Barbry, P.; Maiyar, A.C.; Rozansky, D.J.; Bhargava, A.; Leong, M.; Firestone, G.L.; Pearce, D. SGK integrates insulin and mineralocorticoid regulation of epithelial sodium transport. Am. J. Physiol. Ren. Physiol. 2001, 280, F303-F313.

88. Arteaga, M.F.; Canessa, C.M. Functional specificity of Sgk1 and Akt1 on ENaC activity. Am. J. Physiol. Ren. Physiol. 2005, 289, F90-F96. [CrossRef] [PubMed]

89. Snyder, P.M.; Olson, D.R.; Thomas, B.C. Serum and glucocorticoid-regulated kinase modulates Nedd4-2-mediated inhibition of the epithelial $\mathrm{Na}^{+}$channel. J. Biol. Chem. 2002, 277, 5-8. [CrossRef] [PubMed]

90. Watt, G.B.; Ismail, N.A.S.; Caballero, A.G.; Land, S.C.; Wilson, S.M. Epithelial $\mathrm{Na}^{+}$channel activity in human airway epithelial cells: The role of serum and glucocorticoid-inducible kinase 1. Br. J. Pharmacol. 2012, 166, 1272-1289. [CrossRef] [PubMed]

91. Ismail, N.A.; Baines, D.L.; Wilson, S.M. The phosphorylation of endogenous Nedd4-2 In $\mathrm{Na}^{+}$-absorbing human airway epithelial cells. Eur. J. Pharmacol. 2014, 732, 32-42. [CrossRef] [PubMed]

92. Kuntzsch, D.; Bergann, T.; Dames, P.; Fromm, A.; Fromm, M.; Davis, R.A.; Melzig, M.F.; Schulzke, J.D. The plant-derived glucocorticoid receptor agonist Endiandrin A acts as co-stimulator of colonic epithelial sodium channels (ENaC) via SGK-1 and MAPKs. PLoS ONE 2012, 7, e49426. [CrossRef] [PubMed]

93. Debonneville, C.; Flores, S.Y.; Kamynina, E.; Plant, P.J.; Tauxe, C.; Thomas, M.A.; Munster, C.; Chraibi, A.; Pratt, J.H.; Horisberger, J.D.; et al. Phosphorylation of Nedd4-2 by Sgk1 regulates epithelial $\mathrm{Na}^{+}$channel cell surface expression. EMBO J. 2001, 20, 7052-7059. [CrossRef] [PubMed]

94. He, J.; Qi, D.; Wang, D.-X.; Deng, W.; Ye, Y.; Feng, L.-H.; Zhu, T.; Zhao, Y.; Zhang, C.-R. Insulin upregulates the expression of epithelial sodium channel in vitro and in a mouse model of acute lung injury: Role of mTORC2/SGK1 pathway. Exp. Cell Res. 2015, 331, 164-175. [CrossRef] [PubMed]

95. Vuagniaux, G.; Vallet, V.; Jaeger, N.F.; Hummler, E.; Rossier, B.C. Synergistic activation of ENaC by three membrane-bound channel-activating serine proteases (mCAP1, mCAP2, and mCAP3) and serum- and glucocorticoid-regulated kinase (Sgk1) in Xenopus oocytes. J. Gen. Physiol. 2002, 120, 191-201. [CrossRef] [PubMed]

96. Zhou, R.F.; Kabra, R.; Olson, D.R.; Piper, R.C.; Snyder, P.M. Hrs controls sorting of the epithelial $\mathrm{Na}^{+}$channel between endosomal degradation and recycling pathways. J. Biol. Chem. 2010, 285, 30523-30530. [CrossRef] [PubMed]

97. Lang, F.; Shumilina, E. Regulation of ion channels by the serum- and glucocorticoid-inducible kinase SGK1. FASEB J. 2013, 27, 3-12. [CrossRef] [PubMed]

98. Snyder, P.M. Down-regulating destruction: Phosphorylation regulates the E3 ubiquitin ligase Nedd4-2. Sci. Signal. 2009, 2, pe41. [CrossRef] [PubMed]

99. Nagaki, K.; Yamamura, H.; Shimada, S.; Saito, T.; Hisanaga, S.; Taoka, M.; Isobe, T.; Ichimura, T. 14-3-3 Mediates phosphorylation-dependent inhibition of the interaction between the ubiquitin E3 ligase Nedd4-2 and epithelial $\mathrm{Na}^{+}$channels. Biochemistry 2006, 45, 6733-6740. [PubMed]

100. Staub, O.; Verrey, F. Impact of Nedd4 proteins and serum and glucocorticoid-induced kinases on epithelial $\mathrm{Na}^{+}$transport in the distal nephron. J. Am. Soc. Nephrol. 2005, 16, 3167-3174. [CrossRef] [PubMed]

101. Thomas, C.P.; Itani, O.A. New insights into epithelial sodium channel function in the kidney: Site of action, regulation by ubiquitin ligases, serum- and glucocorticoid-inducible kinase and proteolysis. Curr. Opin. Nephrol. Hypertens. 2004, 13, 541-548. [CrossRef] [PubMed]

102. Yang, B.; Kumar, S. Nedd4 and Nedd4-2: Closely related ubiquitin-protein ligases with distinct physiological functions. Cell Death Differ. 2010, 17, 68-77. [CrossRef] [PubMed]

103. Kamynina, E.; Staub, O. Concerted action of ENaC, Nedd4-2, and Sgk1 in transepithelial $\mathrm{Na}^{+}$transport. Am. J. Physiol. Ren. Physiol. 2002, 283, F377-F387. [CrossRef] [PubMed]

104. Pearce, D. SGK1 regulation of epithelial sodium transport. Cell. Physiol. Biochem. 2003, 13, 13-20. [CrossRef] [PubMed] 
105. Bhalla, V.; Daidie, D.; Li, H.Y.; Pao, A.C.; LaGrange, L.P.; Wang, J.; Vandewalle, A.; Stockand, J.D.; Staub, O.; Pearce, D. Serum- and glucocorticoid-regulated kinase 1 regulates ubiquitin ligase neural precursor cell-expressed, developmentally down-regulated protein 4-2 by inducing interaction with 14-3-3. Mol. Endocrinol. 2005, 19, 3073-3084. [CrossRef] [PubMed]

106. Soundararajan, R.; Melters, D.; Shih, I.C.; Wang, J.; Pearce, D. Epithelial sodium channel regulated by differential composition of a signaling complex. Proc. Natl. Acad. Sci. USA 2009, 106, 7804-7809. [CrossRef] [PubMed]

107. Thomas, S.V.; Kathpalia, P.P.; Rajagopal, M.; Charlton, C.; Zhang, J.N.; Eaton, D.C.; Helms, M.N.; Pao, A.C. Epithelial sodium channel regulation by cell surface-associated serum- and Glucocorticoid-regulated kinase 1. J. Biol. Chem. 2011, 286, 32074-32085. [CrossRef] [PubMed]

108. Soundararajan, R.; Ziera, T.; Koo, E.; Ling, K.; Wang, J.; Borden, S.A.; Pearce, D. Scaffold protein connector enhancer of kinase suppressor of Ras isoform 3 (CNK3) coordinates assembly of a multiprotein epithelial sodium channel (ENaC)-regulatory complex. J. Biol. Chem. 2012, 287, 33014-33025. [CrossRef] [PubMed]

109. Soundararajan, R.; Pearce, D.; Ziera, T. The role of the ENaC-regulatory complex in aldosterone-mediated sodium transport. Mol. Cell. Endocrinol. 2012, 350, 242-247. [CrossRef] [PubMed]

110. Soundararajan, R.; Lu, M.; Pearce, D. Organization of the ENaC-regulatory machinery. Crit. Rev. Biochem. Mol. Biol. 2012, 47, 349-359. [CrossRef] [PubMed]

111. Rotin, D.; Staub, O. Role of the ubiquitin system in regulating ion transport. Pflug. Arch. Eur. J. Physiol. 2011, 461, 1-21. [CrossRef] [PubMed]

112. Edinger, R.S.; Lebowitz, J.; Li, H.; Alzamora, R.; Wang, H.; Johnson, J.P.; Hallows, K.R. Functional regulation of the epithelial $\mathrm{Na}^{+}$channel by IкB kinase- $\beta$ occurs via phosphorylation of the ubiquitin ligase Nedd4-2. J. Biol. Chem. 2009, 284, 150-157. [CrossRef] [PubMed]

113. Zhang, L.; Cui, R.; Cheng, X.; Du, J. Antiapoptotic effect of serum and glucocorticoid-inducible protein kinase is mediated by novel mechanism activating IKB kinase. Cancer Res. 2005, 65, 457-464. [PubMed]

114. Endo, T.; Kusakabe, M.; Sunadome, K.; Yamamoto, T.; Nishida, E. The kinase SGK1 in the endoderm and mesoderm promotes ectodermal survival by down-regulating components of the death-inducing signaling complex. Sci. Signal. 2011, 4, ra2. [CrossRef] [PubMed]

115. Krueger, B.; Haerteis, S.; Yang, L.; Hartner, A.; Rauh, R.; Korbmacher, C.; Diakov, A. Cholesterol depletion of the plasma membrane prevents activation of the epithelial sodium channel (ENaC) by SGK1. Cell. Physiol. Biochem. 2009, 24, 605-618. [CrossRef] [PubMed]

116. Diakov, A.; Korbmacher, C. A novel pathway of epithelial sodium channel activation involves a serum- and glucocorticoid-inducible kinase consensus motif in the $\mathrm{C}$ terminus of the channel's $\alpha$-subunit. J. Biol. Chem. 2004, 279, 38134-38142. [CrossRef] [PubMed]

117. Liang, X.B.; Butterworth, M.B.; Peters, K.W.; Frizzell, R.A. AS160 modulates aldosterone-stimulated epithelial sodium channel forward trafficking. Mol. Biol. Cell 2010, 21, 2024-2033. [CrossRef] [PubMed]

118. Ring, A.M.; Leng, Q.; Rinehart, J.; Wilson, F.H.; Kahle, K.T.; Hebert, S.C.; Lifton, R.P. An SGK1 site in WNK4 regulates $\mathrm{Na}^{+}$channel and $\mathrm{K}^{+}$channel activity and has implications for aldosterone signaling and $\mathrm{K}^{+}$ homeostasis. Proc. Natl. Acad. Sci. USA 2007, 104, 4025-4029. [CrossRef] [PubMed]

119. Heise, C.J.; Xu, B.E.; Deaton, S.L.; Cha, S.K.; Cheng, C.J.; Earnest, S.; Sengupta, S.; Juang, Y.C.; Stippec, S.; $\mathrm{Xu}$, Y.D.; et al. Serum and glucocorticoid-induced kinase (SGK) 1 and the epithelial sodium channel are regulated by multiple with no lysine (WNK) family members. J. Biol. Chem. 2010, 285, 25161-25167. [CrossRef] [PubMed]

120. Hoorn, E.J.; Nelson, J.H.; McCormick, J.A.; Ellison, D.H. The WNK kinase network regulating sodium, potassium, and blood pressure. J. Am. Soc. Nephrol. 2011, 22, 605-614. [CrossRef] [PubMed]

121. Helms, M.N.; Yu, L.; Malik, B.; Kleinhenz, D.J.; Hart, C.M.; Eaton, D.C. Role of SGK1 in nitric oxide inhibition of ENaC in $\mathrm{Na}^{+}$-transporting epithelia. Am. J. Physiol. Cell Physiol. 2005, 289, C717-C726. [CrossRef] [PubMed]

122. Hyndman, K.A.; Bugaj, V.; Mironova, E.; Stockand, J.D.; Pollock, J.S. NOS1-dependent negative feedback regulation of the epithelial sodium channel in the collecting duct. Am. J. Physiol. Ren. Physiol. 2015, 308, F244-F251. [CrossRef] [PubMed]

123. Boyd, C.; Toth, A.N.F. Gene regulation of ENaC subunits by serum- and glucocorticoid-inducible kinase-1. Am. J. Physiol. Ren. Physiol. 2005, 288, F505-F512. [CrossRef] [PubMed] 
124. Zhang, W.Z.; Xia, X.F.; Reisenauer, M.R.; Rieg, T.; Lang, F.; Kuhl, D.; Vallon, V.; Kone, B.C. Aldosterone-induced Sgk1 relieves Dot1a-Af9-mediated transcriptional repression of epithelial $\mathrm{Na}^{+}$ channel $\alpha$. J. Clin. Investig. 2007, 117, 773-783. [CrossRef] [PubMed]

125. Zhang, D.Y.; Yu, Z.Y.; Cruz, P.; Kong, Q.; Li, S.Y.; Kone, B.C. Epigenetics and the control of epithelial sodium channel expression in collecting duct. Kidney Int. 2009, 75, 260-267. [CrossRef] [PubMed]

126. Chen, L.; Zhang, X.; Zhang, W. Regulation of $\alpha$ ENaC transcription. Vitam. Horm. 2015, 98, 101-135. [PubMed]

127. Wu, H.Y.; Chen, L.H.; Zhou, Q.L.; Zhang, W.Z. AF17 Facilitates dot1a nuclear export and upregulates ENaC-mediated $\mathrm{Na}^{+}$transport in renal collecting duct cells. PLoS ONE 2011, 6, e27429. [CrossRef] [PubMed]

128. Reisenauer, M.R.; Wang, S.W.; Xia, Y.; Zhang, W. Dot1a contains three nuclear localization signals and regulates the epithelial $\mathrm{Na}^{+}$channel $(\mathrm{ENaC})$ at multiple levels. Am. J. Physiol. Ren. Physiol. 2010, 299, F63-F76. [CrossRef] [PubMed]

129. Duarte, J.D.; Zineh, I.; Burkley, B.; Gong, Y.; Langaee, T.Y.; Turner, S.T.; Chapman, A.B.; Boerwinkle, E.; Gums, J.G.; Cooper-Dehoff, R.M.; et al. Effects of genetic variation in H3K79 methylation regulatory genes on clinical blood pressure and blood pressure response to hydrochlorothiazide. J. Transl. Med. 2012, 10, 56. [CrossRef] [PubMed]

130. Reisenauer, M.R.; Anderson, M.; Huang, L.; Zhang, Z.; Zhou, Q.; Kone, B.C.; Morris, A.P.; Lesage, G.D.; Dryer, S.E.; Zhang, W. AF17 competes with AF9 for binding to Dot1a to up-regulate transcription of epithelial $\mathrm{Na}^{+}$channel $\alpha$. J. Biol. Chem. 2009, 284, 35659-35669. [CrossRef] [PubMed]

131. McTavish, N.; Getty, J.; Burchell, A.; Wilson, S.M. Glucocorticoids can activate the $\alpha$-ENaC gene promoter independently of SGK1. Biochem. J. 2009, 423, 189-197. [CrossRef] [PubMed]

132. Bezzerides, V.; Simonson, B.; Das, S.; Rosenzweig, A. Dual kinase control of cardiac sodium channel activity. Heart Rhythm. Conf. 2013, 10, S52-S53.

133. Boehmer, C.; Wilhelm, V.; Palmada, M.; Wallisch, S.; Henke, G.; Brinkmeier, H.; Cohen, P.; Pieske, B.; Lang, F. Serum and glucocorticoid inducible kinases in the regulation of the cardiac sodium channel SCN5A. Cardiovasc. Res. 2003, 57, 1079-1084. [CrossRef]

134. Das, S.; Aiba, T.; Rosenberg, M.; Hessler, K.; Xiao, C.Y.; Quintero, P.A.; Ottaviano, F.G.; Knight, A.C.; Graham, E.L.; Bostrom, P.; et al. Pathological role of serum- and glucocorticoid-regulated kinase 1 in adverse ventricular remodeling. Circulation 2012, 126, 2208-2219. [CrossRef] [PubMed]

135. Marionneau, C.; Abriel, H. Regulation of the cardiac $\mathrm{Na}^{+}$channel $\mathrm{Na}_{\mathrm{V}} 1.5$ by post-translational modifications. J. Mol. Cell. Cardiol. 2015, 82, 36-47. [CrossRef] [PubMed]

136. Stevens, V.A.; Saad, S.; Poronnik, P.; Fenton-Lee, C.A.; Polhill, T.S.; Pollock, C.A. The role of SGK-1 in angiotensin II-mediated sodium reabsorption in human proximal tubular cells. Nephrol. Dial. Transplant. 2008, 23, 1834-1843. [CrossRef] [PubMed]

137. Vallon, V.; Lang, F. New insights into role of serum- and glucorticoid-inducible kinase SGK1 in the regulation of renal function and blood pressure. Curr. Opin. Nephrol. Hypertens. 2005, 14, 59-66. [CrossRef] [PubMed]

138. Dynia, D.W.; Steinmetz, A.G.; Kocinsky, H.S. NHE3 function and phosphorylation are regulated by a calyculin A-sensitive phosphatase. Am. J. Physiol. Ren. Physiol. 2010, 298, F745-F753. [CrossRef] [PubMed]

139. Wang, D.S.; Sun, H.; Lang, F.; Yun, C.C. Activation of NHE3 by dexamethasone requires phosphorylation of NHE3 at Ser663 by SGK1. Am. J. Physiol. Cell Physiol. 2005, 289, C802-C810. [CrossRef] [PubMed]

140. Wang, D.; Zhang, H.; Lang, F.; Yun, C.C. Acute activation of NHE3 by dexamethasone correlates with activation of SGK1 and requires a functional glucocorticoid receptor. Am. J. Physiol. Cell Physiol. 2007, 292, C396-C404. [CrossRef] [PubMed]

141. Yun, C.C. Concerted roles of SGK1 and the $\mathrm{Na}^{+} / \mathrm{H}^{+}$exchanger regulatory factor 2 (NHERF2) in regulation of NHE3. Cell. Physiol. Biochem. 2003, 13, 29-40. [CrossRef] [PubMed]

142. He, P.J.; Lee, S.J.; Lin, S.B.; Seidler, U.; Lang, F.; Fejes-Toth, G.; Naray-Fejes-Toth, A.; Yun, C.C. Serum- and glucocorticoid-induced kinase 3 in recycling endosomes mediates acute activation of $\mathrm{Na}^{+} / \mathrm{H}^{+}$exchanger NHE3 by glucocorticoids. Mol. Biol. Cell 2011, 22, 3812-3825. [CrossRef] [PubMed]

143. Voelkl, J.; Pasham, V.; Ahmed, M.S.E.; Walker, B.; Szteyn, K.; Kuhl, D.; Metzler, B.; Alesutan, I.; Lang, F. Sgk1-dependent stimulation of cardiac $\mathrm{Na}^{+} / \mathrm{H}^{+}$exchanger Nhe1 by dexamethasone. Cell. Physiol. Biochem. 2013, 32, 25-38. [CrossRef] [PubMed] 
144. Voelkl, J.; Lin, Y.; Alesutan, I.; Ahmed, M.S.; Pasham, V.; Mia, S.; Gu, S.; Feger, M.; Saxena, A.; Metzler, B.; et al. Sgk1 sensitivity of $\mathrm{Na}^{+} / \mathrm{H}^{+}$exchanger activity and cardiac remodeling following pressure overload. Basic Res. Cardiol. 2012, 107, 236. [CrossRef] [PubMed]

145. Xu, L.; Pan, L.; Li, J.; Huang, B.; Feng, J.; Li, C.; Wang, S.; The, E.; Liu, Y.; Yuan, T.; et al. Nucleoporin 35 regulates cardiomyocyte $\mathrm{pH}$ homeostasis by controlling $\mathrm{Na}^{+}-\mathrm{H}^{+}$exchanger-1 expression. J. Mol. Cell Biol. 2015, 7, 476-485. [CrossRef] [PubMed]

146. Mohamed, I.A.; Gadeau, A.P.; Fliegel, L.; Lopaschuk, G.; Mlih, M.; Abdulrahman, N.; Fillmore, N.; Mraiche, F. $\mathrm{Na}^{+} / \mathrm{H}^{+}$exchanger isoform 1-induced osteopontin expression facilitates cardiomyocyte hypertrophy. PLOS ONE 2015, 10, e0123318. [CrossRef] [PubMed]

147. Mlih, M.; Abdulrahman, N.; Gadeau, A.P.; Mohamed, I.A.; Jaballah, M.; Mraiche, F. $\mathrm{Na}^{+} / \mathrm{H}^{+}$exchanger isoform 1 induced osteopontin expression in cardiomyocytes involves NFAT3/Gata4. Mol. Cell. Biochem. 2015, 404, 211-220. [CrossRef] [PubMed]

148. Vallon, V.; Schroth, J.; Lang, F.; Kuhl, D.; Uchida, S. Expression and phosphorylation of the $\mathrm{Na}^{+}-\mathrm{Cl}^{-}$ cotransporter NCC in vivo is regulated by dietary salt, potassium, and SGK1. Am. J. Physiol. Ren. Physiol. 2009, 297, F704-F712. [CrossRef] [PubMed]

149. Moes, A.D.; van der Lubbe, N.; Zietse, R.; Loffing, J.; Hoorn, E.J. The sodium chloride cotransporter SLC12A3: New roles in sodium, potassium, and blood pressure regulation. Pflug. Arch. Eur. J. Physiol. 2014, 466, 107-118. [CrossRef] [PubMed]

150. Roy, A.; Al-Qusairi, L.; Donnelly, B.F.; Ronzaud, C.; Marciszyn, A.L.; Gong, F.; Chang, Y.P.C.; Butterworth, M.B.; Pastor-Soler, N.M.; Hallows, K.R.; et al. Alternatively spliced proline-rich cassettes link WNK1 to aldosterone action. J. Clin. Investig. 2015, 125, 3433-3448. [CrossRef] [PubMed]

151. Dimke, H. Exploring the intricate regulatory network controlling the thiazide-sensitive $\mathrm{NaCl}$ cotransporter (NCC). Pflug. Arch. Eur. J. Physiol. 2011, 462, 767-777. [CrossRef] [PubMed]

152. Van der Lubbe, N.; Lim, C.H.; Fenton, R.A.; Meima, M.E.; Danser, A.H.J.; Zietse, R.; Hoorn, E.J. Angiotensin II induces phosphorylation of the thiazide-sensitive sodium chloride cotransporter independent of aldosterone. Kidney Int. 2011, 79, 66-76. [CrossRef] [PubMed]

153. Zhou, B.; Zhuang, J.; Gu, D.; Wang, H.; Cebotaru, L.; Guggino, W.B.; Cai, H. WNK4 enhances the degradation of NCC through a sortilin-mediated lysosomal pathway. J. Am. Soc. Nephrol. 2010, 21, 82-92. [CrossRef] [PubMed]

154. Yang, C.L.; Angell, J.; Mitchell, R.; Ellison, D.H. WNK kinases regulate thiazide-sensitive Na-Cl cotransport. J. Clin. Investig. 2003, 111, 1039-1045. [CrossRef] [PubMed]

155. Rozansky, D.J.; Cornwall, T.; Subramanya, A.R.; Rogers, S.; Yang, Y.F.; David, L.L.; Zhu, X.M.; Yang, C.L.; Ellison, D.H. Aldosterone mediates activation of the thiazide-sensitive Na-Cl cotransporter through an SGK1 and WNK4 signaling pathway. J. Clin. Investig. 2009, 119, 2601-2612. [CrossRef] [PubMed]

156. Arroyo, J.P.; Lagnaz, D.; Ronzaud, C.; Vazquez, N.; Ko, B.S.; Moddes, L.; Ruffieux-Daidie, D.; Hausel, P.; Koesters, R.; Yang, B.L.; et al. Nedd4-2 modulates renal $\mathrm{Na}^{+}-\mathrm{Cl}^{-}$cotransporter via the aldosterone-SGK1-Nedd4-2 pathway. J. Am. Soc. Nephrol. 2011, 22, 1707-1719. [CrossRef] [PubMed]

157. Ko, B.; Mistry, A.C.; Hanson, L.; Mallick, R.; Wynne, B.M.; Thai, T.L.; Bailey, J.L.; Klein, J.D.; Hoover, R.S. Aldosterone acutely stimulates NCC activity via a SPAK-mediated pathway. Am. J. Physiol. Ren. Physiol. 2013, 305, F645-F652. [CrossRef] [PubMed]

158. Rotin, D.; Staub, O. Nedd4-2 and the regulation of epithelial sodium transport. Front. Physiol. $2012,3,212$. [CrossRef] [PubMed]

159. Artunc, F.; Ebrahim, A.; Siraskar, B.; Nasir, O.; Rexhepaj, R.; Amann, K.; Friedrich, B.; Risler, T.; Lang, F. Responses to diuretic treatment in gene-targeted mice lacking serum- and glucocorticoid-inducible kinase 1. Kidney Blood Press. Res. 2009, 32, 119-127. [CrossRef] [PubMed]

160. Lang, F.; Klingel, K.; Wagner, C.A.; Stegen, C.; Warntges, S.; Friedrich, B.; Lanzendorfer, M.; Melzig, J.; Moschen, I.; Steuer, S.; et al. Deranged transcriptional regulation of cell-volume-sensitive kinase hSGK in diabetic nephropathy. Proc. Natl. Acad. Sci. USA 2000, 97, 8157-8162. [CrossRef] [PubMed]

161. Warntges, S.; Grone, H.J.; Capasso, G.; Lang, F. Cell volume regulatory mechanisms in progression of renal disease. J. Nephrol. 2001, 14, 319-326. [PubMed]

162. Alvarez de la Rosa, D.; Gimenez, I.; Forbush, B.; Canessa, C.M. SGK1 activates $\mathrm{Na}^{+}-\mathrm{K}^{+}$-ATPase in amphibian renal epithelial cells. Am. J. Physiol. Cell Physiol. 2006, 290, C492-C498. [CrossRef] [PubMed] 
163. Pao, A.C. SGK regulation of renal sodium transport. Curr. Opin. Nephrol. Hypertens. 2012, 21, 534-540. [CrossRef] [PubMed]

164. Setiawan, I.; Henke, G.; Feng, Y.X.; Bohmer, C.; Vasilets, L.A.; Schwarz, W.; Lang, F. Stimulation of Xenopus oocyte $\mathrm{Na}^{+}, \mathrm{K}^{+}$ATPase by the serum and glucocorticoid-dependent kinase sgk1. Pflug. Arch.: Eur. J. Physiol. 2002, 444, 426-431. [CrossRef] [PubMed]

165. Verrey, F.; Summa, V.; Heitzmann, D.; Mordasini, D.; Vandewalle, A.; Feraille, E.; Zecevic, M. Short-term aldosterone action on Na,K-ATPase surface expression: Role of aldosterone-induced SGK1? Ann. N. Y. Acad. Sci. 2003, 986, 554-561. [CrossRef] [PubMed]

166. Zecevic, M.; Heitzmann, D.; Camargo, S.M.R.; Verrey, F. SGK1 increases Na,K-ATP cell-surface expression and function in Xenopus laevis oocytes. Pflug. Arch. Eur. J. Physiol. 2004, 448, 29-35. [CrossRef] [PubMed]

167. Henke, G.; Setiawan, I.; Bohmer, C.; Lang, F. Activation of $\mathrm{Na}^{+} / \mathrm{K}^{+}$-ATPase by the serum and glucocorticoid-dependent kinase isoforms. Kidney Blood Press. Res. 2002, 25, 370-374. [CrossRef] [PubMed]

168. Waldegger, S.; Barth, P.; Forrest, J.N., Jr.; Greger, R.; Lang, F. Cloning of sgk serine-threonine protein kinase from shark rectal gland-A gene induced by hypertonicity and secretagogues. Pflug. Arch. Eur. J. Physiol. 1998, 436, 575-580. [CrossRef] [PubMed]

169. Waldegger, S.; Erdel, M.; Nagl, U.O.; Barth, P.; Raber, G.; Steuer, S.; Utermann, G.; Paulmichl, M.; Lang, F. Genomic organization and chromosomal localization of the human SGK protein kinase gene. Genomics 1998, 51, 299-302. [CrossRef] [PubMed]

170. Chen, S.; McCormick, J.A.; Prabaker, K.; Wang, J.; Pearce, D.; Gardner, D.G. Sgk1 mediates osmotic induction of NPR-A gene in rat inner medullary collecting duct cells. Hypertension 2004, 43, 866-871. [CrossRef] [PubMed]

171. Chandran, S.; Li, H.; Dong, W.X.; Krasinska, K.; Adams, C.; Alexandrova, L.; Chien, A.; Hallows, K.R.; Bhalla, V. Neural precursor cell-expressed developmentally down-regulated protein 4-2 (Nedd4-2) regulation by 14-3-3 protein binding at canonical serum and glucocorticoid kinase 1 (SGK1) phosphorylation sites. J. Biol. Chem. 2011, 286, 37830-37840. [CrossRef] [PubMed]

172. Lang, F.; Artunc, F.; Vallon, V. The physiological impact of the serum and glucocorticoid-inducible kinase SGK1. Curr. Opin. Nephrol. Hypertens. 2009, 18, 439-448. [CrossRef] [PubMed]

173. Lang, F.; Pearce, D. Regulation of the epithelial $\mathrm{Na}^{+}$channel by the mTORC2/SGK1 pathway. Nephrol. Dial. Transplant. 2016, 31, 200-205. [CrossRef] [PubMed]

174. Robert-Nicoud, M.; Flahaut, M.; Elalouf, J.M.; Nicod, M.; Salinas, M.; Bens, M.; Doucet, A.; Wincker, P.; Artiguenave, F.; Horisberger, J.D.; et al. Transcriptome of a mouse kidney cortical collecting duct cell line: Effects of aldosterone and vasopressin. Proc. Natl. Acad. Sci. USA 2001, 98, 2712-2716. [CrossRef] [PubMed]

175. Bhargava, A.; Fullerton, M.J.; Myles, K.; Purdy, T.M.; Funder, J.W.; Pearce, D.; Cole, T.J. The serum- and glucocorticoid-induced kinase is a physiological mediator of aldosterone action. Endocrinology 2001, 142, 1587-1594. [CrossRef] [PubMed]

176. Foo, R.; O'Shaughnessy, K.M.; Brown, M.J. Hyperaldosteronism: Recent concepts, diagnosis, and management. Postgrad. Med. J. 2001, 77, 639-644. [CrossRef] [PubMed]

177. Lu, M.; Wang, J.; Jones, K.T.; Ives, H.E.; Feldman, M.E.; Yao, L.J.; Shokat, K.M.; Ashrafi, K.; Pearce, D. mTOR complex-2 activates ENaC by phosphorylating SGK1. J. Am. Soc. Nephrol. 2010, 21, 811-818. [CrossRef] [PubMed]

178. McDonald, F.J. A new SGK1 knockout mouse. Am. J. Physiol. Ren. Physiol. 2008, 294, F1296-F1297. [CrossRef] [PubMed]

179. Kemp, B.A.; Howell, N.L.; Gildea, J.J.; Keller, S.R.; Padia, S.H. Intrarenal ghrelin receptors regulate ENaC-dependent sodium reabsorption by a cAMP-dependent pathway. Kidney Int. 2013, 84, 501-508. [CrossRef] [PubMed]

180. Samavat, S.; Ahmadpoor, P. Aldosterone, hypertension, and beyond. Iran. J. Kidney Dis. 2011, 5, 71-76. [PubMed]

181. Fuster, D.G.; Bobulescu, I.A.; Zhang, J.; Wade, J.; Moe, O.W. Characterization of the regulation of renal $\mathrm{Na}^{+} / \mathrm{H}^{+}$exchanger NHE3 by insulin. Am. J. Physiol. Ren. Physiol. 2007, 292, F577-F585. [CrossRef] [PubMed]

182. Vallon, V.; Wulff, P.; Huang, D.Y.; Loffing, J.; Volkl, H.; Kuhl, D.; Lang, F. Role of Sgk1 in salt and potassium homeostasis. Am. J. Physiol. Regul. Integr. Comp. Physiol. 2005, 288, R4-R10. [CrossRef] [PubMed] 
183. Salyer, S.A.; Parks, J.; Barati, M.T.; Lederer, E.D.; Clark, B.J.; Klein, J.D.; Khundmiri, S.J. Aldosterone regulates $\mathrm{Na}^{+}, \mathrm{K}^{+}$ATPase activity in human renal proximal tubule cells through mineralocorticoid receptor. Biochim. Biophys. Acta Mol. Cell Res. 2013, 1833, 2143-2152. [CrossRef] [PubMed]

184. Saad, S.; Agapiou, D.J.; Chen, X.M.; Stevens, V.; Pollock, C.A. The role of Sgk-1 in the upregulation of transport proteins by PPAR $\gamma$ agonists in human proximal tubule cells. Nephrol. Dial. Transplant. 2009, 24, 1130-1141. [CrossRef] [PubMed]

185. Gleason, C.E.; Frindt, G.; Cheng, C.J.; Ng, M.; Kidwai, A.; Rashmi, P.; Lang, F.; Baum, M.; Palmer, L.G.; Pearce, D. mTORC2 regulates renal tubule sodium uptake by promoting ENaC activity. J. Clin. Investig. 2015, 125, 117-128. [CrossRef] [PubMed]

186. Faresse, N.; Lagnaz, D.; Debonneville, A.; Ismailji, A.; Maillard, M.; Fejes-Toth, G.; Naray-Fejes-Toth, A.; Staub, O. Inducible kidney-specific Sgk1 knockout mice show a salt-losing phenotype. Am. J. Physiol. Ren. Physiol. 2012, 302, F977-F985. [CrossRef] [PubMed]

187. Lang, F.; Henke, G.; Embark, H.M.; Waldegger, W.; Palmada, M.; Bohmer, C.; Vallon, V. Regulation of channels by the serum and glucocorticoid-inducible kinase-implications for transport, excitability and cell proliferation. Cell. Physiol. Biochem. 2003, 13, 41-50. [CrossRef] [PubMed]

188. Wulff, P.; Vallon, V.; Huang, D.Y.; Volkl, H.; Yu, F.; Richter, K.; Jansen, M.; Schlunz, M.; Klingel, K.; Loffing, J.; et al. Impaired renal $\mathrm{Na}^{+}$retention in the sgk1-knockout mouse. J. Clin. Investig. 2002, 110, 1263-1268. [CrossRef] [PubMed]

189. Lang, F.; Capasso, G.; Schwab, M.; Waldegger, S. Renal tubular transport and the genetic basis of hypertensive disease. Clin. Exp. Nephrol. 2005, 9, 91-99. [CrossRef] [PubMed]

190. Tang, C.; Zelenak, C.; Volkl, J.; Eichenmuller, M.; Regel, I.; Frohlich, H.; Kempe, D.; Jimenez, L.; Le Bellego, L.; Vergne, S.; et al. Hydration-sensitive gene expression in brain. Cell. Physiol. Biochem. 2011, 27, 757-768. [CrossRef] [PubMed]

191. Leong, M.L.L.; Maiyar, A.C.; Kim, B.; O'Keeffe, B.A.; Firestone, G.L. Expression of the serum- and glueocorticoid-inducible protein kinase, Sgk, is a cell survival response to multiple types of environmental stress stimuli in mammary epithelial cells. J. Biol. Chem. 2003, 278, 5871-5882. [CrossRef] [PubMed]

192. Taruno, A.; Niisato, N.; Marunaka, Y. Intracellular calcium plays a role as the second messenger of hypotonic stress in gene regulation of SGK1 and ENaC in renal epithelial A6 cells. Am. J. Physiol. Ren. Physiol. 2008, 294, F177-F186. [CrossRef] [PubMed]

193. Rozansky, D.J.; Wang, J.; Doan, N.; Purdy, T.; Faulk, T.; Bhargava, A.; Dawson, K.; Pearce, D. Hypotonic induction of SGK1 and $\mathrm{Na}^{+}$transport in A6 cells. Am. J. Physiol. Ren. Physiol. 2002, 283, F105-F113. [CrossRef] [PubMed]

194. Cat, A.N.D.; Ouvrard-Pascaud, A.; Tronche, F.; Clemessy, M.; Gonzalez-Nunez, D.; Farman, N.; Jaisser, F. Conditional transgenic mice for studying the role of the glucocorticoid receptor in the renal collecting duct. Endocrinology 2009, 150, 2202-2210.

195. Lee, S.M.; Lee, Y.J.; Yoon, J.J.; Kang, D.G.; Lee, H.S. Effect of Poria cocos on hypertonic stress-induced water channel expression and apoptosis in renal collecting duct cells. J. Ethnopharmacol. 2012, 141, 368-376. [CrossRef] [PubMed]

196. Bell, L.M.; Leong, M.L.L.; Kim, B.; Wang, E.; Park, J.; Hemmings, B.A.; Firestone, G.L. Hyperosmotic stress stimulates promoter activity and regulates cellular utilization of the serum- and glucocorticoid-inducible protein kinase (SGK)by a p38 MAPK-dependent pathway. J. Biol. Chem. 2000, 275, 25262-25272. [CrossRef] [PubMed]

197. Vallon, V.; Huang, D.Y.; Grahammer, F.; Wyatt, A.W.; Osswald, H.; Wulff, P.; Kuhl, D.; Lang, F. SGK1 as a determinant of kidney function and salt intake in response to mineralocorticoid excess. Am. J. Physiol. Regul. Integr. Comp. Physiol. 2005, 289, R395-R401. [CrossRef] [PubMed]

198. Farjah, M.; Roxas, B.P.; Geenen, D.L.; Danziger, R.S. Dietary salt regulates renal SGK1 abundance: Relevance to salt sensitivity in the Dahl rat. Hypertension 2003, 41, 874-878. [CrossRef] [PubMed]

199. Fu, Y.; Vallon, V. Mineralocorticoid-induced sodium appetite and renal salt retention: Evidence for common signaling and effector mechanisms. Nephron Physiol. 2014, 128, 8-16. [CrossRef] [PubMed]

200. Umbach, A.T.; Pathare, G.; Foller, M.; Brosens, J.J.; Artunc, F.; Lang, F. SGK1-dependent salt appetite in pregnant mice. Acta Physiol. 2011, 202, 39-45. [CrossRef] [PubMed] 
201. Aoi, W.; Niisato, N.; Sawabe, Y.; Miyazaki, H.; Marunaka, Y. Aldosterone-induced abnormal regulation of ENaC and SGK1 in Dahl salt-sensitive rat. Biochem. Biophy. Res. Commun. 2006, 341, 376-381. [CrossRef] [PubMed]

202. Huang, D.Y.; Boini, K.M.; Osswald, H.; Friedrich, B.; Artunc, F.; Ullrich, S.; Rajamanickam, J.; Palmada, M.; Wulff, P.; Kuhl, D.; et al. Resistance of mice lacking the serum- and glucocorticoid-inducible kinase SGK1 against salt-sensitive hypertension induced by a high-fat diet. Am. J. Physiol. Ren. Physiol. 2006, 291, F1264-F1273. [CrossRef] [PubMed]

203. Huang, D.Y.; Boini, K.M.; Friedrich, B.; Metzger, M.; Just, L.; Osswald, H.; Wulff, P.; Kuhl, D.; Vallon, V.; Lang, F. Blunted hypertensive effect of combined fructose and high-salt diet in gene-targeted mice lacking functional serum- and glucocorticoid-inducible kinase SGK1. Am. J. Physiol. Regul. Integr. Comp. Physiol. 2006, 290, R935-R944. [CrossRef] [PubMed]

204. Aoi, W.; Niisato, N.; Sawabe, Y.; Miyazaki, H.; Tokuda, S.; Nishio, K.; Yoshikawa, T.; Marunaka, Y. Abnormal expression of ENaC and SGK1 mRNA induced by dietary sodium in Dahl salt-sensitively hypertensive rats. Cell Biol. Int. 2007, 31, 1288-1291. [CrossRef] [PubMed]

205. Ito, K.; Hirooka, Y.; Sunagawa, K. Miso (Japanese soybean paste) soup attenuates salt-induced sympathoexcitation and left ventricular dysfunction in mice with chronic pressure overload. Hukuoka Acta Med. 2014, 105, 48-56. [PubMed]

206. Lu, X.; Li, M.; Zhou, L.; Jiang, H.; Wang, H.; Chen, J. Urinary serum- and glucocorticoid-inducible kinase SGK1 reflects renal injury in patients with immunoglobulin A nephropathy. Nephrology 2014, 19, 307-317. [CrossRef] [PubMed]

207. Coric, T.; Hernandez, N.; de la Rosa, D.A.; Shao, D.; Wang, T.; Canessa, C.M. Expression of ENaC and serumand glucocorticoid-induced kinase 1 in the rat intestinal epithelium. Am. J. Physiol. Gastrointest. Liver Physiol. 2004, 286, G663-G670. [CrossRef] [PubMed]

208. Dames, P.; Bergann, T.; Fromm, A.; Bucker, R.; Barmeyer, C.; Krug, S.M.; Fromm, M.; Schulzke, J.-D. Interleukin-13 affects the epithelial sodium channel in the intestine by coordinated modulation of STAT6 and p38 MAPK activity. J. Physiol. 2015, 593, 5269-5282. [CrossRef] [PubMed]

209. Kato, A.; Romero, M.F. Regulation of electroneutral $\mathrm{NaCl}$ absorption by the small intestine. Annu. Rev. Physiol. 2011, 73, 261-281. [CrossRef] [PubMed]

210. Musch, M.W.; Lucioni, A.; Chang, E.B. Aldosterone regulation of intestinal Na absorption involves SGK-mediated changes in NHE3 and $\mathrm{Na}^{+}$pump activity. Am. J. Physiol. Gastrointest. Liver Physiol. 2008, 295, G909-G919. [CrossRef] [PubMed]

211. Keller-Wood, M.; Wood, C.E.; Hua, Y.; Zhang, D. Mineralocorticoid receptor expression in late-gestation ovine fetal lung. J. Soc. Gynecol. Investig. 2005, 12, 84-91. [CrossRef] [PubMed]

212. Li, T.; Koshy, S.; Folkesson, H.G. IL-1 $\beta$-induced cortisol stimulates lung fluid absorption in fetal guinea pigs via SGK-mediated Nedd4-2 inhibition. Am. J. Physiol. Lung Cell. Mol. Physiol. 2009, 296, L527-L533. [CrossRef] [PubMed]

213. Wirbelauer, J.; Schmidt, B.; Klingel, K.; Cao, L.; Lang, F.; Speer, C.P. Serum and glucocorticoid-inducible kinase in pulmonary tissue of preterm fetuses exposed to chorioamnionitis. Neonatology 2008, 93, 257-262. [CrossRef] [PubMed]

214. Janer, C.; Pitkanen, O.M.; Suvari, L.; Turpeinen, U.; Palojarvi, A.; Andersson, S.; Helve, O. Duration of gestation and mode of delivery affect the genes of transepithelial sodium transport in pulmonary adaptation. Neonatology 2015, 107, 27-33. [CrossRef] [PubMed]

215. Pondugula, S.R.; Raveendran, N.N.; Ergonul, Z.; Deng, Y.P.; Chen, J.; Sanneman, J.D.; Palmer, L.G.; Marcus, D.C. Glucocorticoid regulation of genes in the amiloride-sensitive sodium transport pathway by semicircular canal duct epithelium of neonatal rat. Physiol. Genom. 2006, 24, 114-123. [CrossRef] [PubMed]

216. Zhong, S.X.; Hu, G.H.; Liu, Z.H. Expression of ENaC, SGK1 and Nedd4 isoforms in the cochlea of guinea pig. Folia Histochem. Cytobiol. 2014, 52, 144-148. [CrossRef] [PubMed]

217. Rao, A.D.; Sun, B.; Saxena, A.; Hopkins, P.N.; Jeunemaitre, X.; Brown, N.J.; Adler, G.K.; Williams, J.S. Polymorphisms in the serum- and glucocorticoid-inducible kinase 1 gene are associated with blood pressure and renin response to dietary salt intake. J. Hum. Hypertens. 2013, 27, 176-180. [CrossRef] [PubMed]

218. Strazzullo, P.; Galletti, F.; Barba, G. Altered renal handling of sodium in human hypertension: Short review of the evidence. Hypertension 2003, 41, 1000-1005. [CrossRef] [PubMed] 
219. Boini, K.M.; Hennige, A.M.; Huang, D.Y.; Friedrich, B.; Palmada, M.; Boehmer, C.; Grahammer, F.; Artunc, F.; Ullrich, S.; Avram, D.; et al. Serum- and glucocorticoid-inducible kinase 1 mediates salt sensitivity of glucose tolerance. Diabetes 2006, 55, 2059-2066. [CrossRef] [PubMed]

220. Huang, B.S.; Amin, M.S.; Leenen, F.H.H. The central role of the brain in salt-sensitive hypertension. Curr. Opin. Cardiol. 2006, 21, 295-304. [CrossRef] [PubMed]

221. Mansley, M.K.; Wilson, S.M. Dysregulation of epithelial $\mathrm{Na}^{+}$absorption induced by inhibition of the kinases TORC1 and TORC2. Br. J. Pharmacol. 2010, 161, 1778-1792. [CrossRef] [PubMed]

222. Xu, W.; Huang, Y.; Li, L.; Sun, Z.; Shen, Y.; Xing, J.; Li, M.; Su, D.; Liang, X. Hyperuricemia induces hypertension through activation of renal epithelial sodium channel (ENaC). Metabolism 2016, 65, 73-83. [CrossRef] [PubMed]

223. Auberson, M.; Hoffman-Pochon, N.; Vandewalle, A.; Kellenberger, S.; Schild, L. Epithelial Na ${ }^{+}$channel mutants causing Liddle's syndrome retain ability to respond to aldosterone and vasopressin. Am. J. Physiol. Ren. Physiol. 2003, 285, F459-F471. [CrossRef] [PubMed]

224. Bertog, M.; Cuffe, J.E.; Pradervand, S.; Hummler, E.; Hartner, A.; Porst, M.; Hilgers, K.F.; Rossier, B.C.; Korbmacher, $\mathrm{C}$. Aldosterone responsiveness of the epithelial sodium channel (ENaC) in colon is increased in a mouse model for Liddle's syndrome. J. Physiol. 2008, 586, 459-475. [CrossRef] [PubMed]

225. Vitzthum, H.; Seniuk, A.; Schulte, L.H.; Muller, M.L.; Hetz, H.; Ehmke, H. Functional coupling of renal $\mathrm{K}^{+}$and $\mathrm{Na}^{+}$handling causes high blood pressure in $\mathrm{Na}^{+}$replete mice. J. Physiol. 2014, 592, 1139-1157. [CrossRef] [PubMed]

226. Busjahn, A.; Luft, F.C. Twin studies in the analysis of minor physiological differences between individuals. Cell. Physiol. Biochem. 2003, 13, 51-58. [CrossRef] [PubMed]

227. Busjahn, A.; Aydin, A.; Uhlmann, R.; Krasko, C.; Bahring, S.; Szelestei, T.; Feng, Y.X.; Dahm, S.; Sharma, A.M.; Luft, F.C.; et al. Serum- and glucocorticoid-regulated kinase (SGK1) gene and blood pressure. Hypertension 2002, 40, 256-260. [CrossRef] [PubMed]

228. Trochen, N.; Ganapathipillai, S.; Ferrari, P.; Frey, B.M.; Frey, F.J. Low prevalence of nonconservative mutations of serum and glucocorticoid-regulated kinase (SGK1) gene in hypertensive and renal patients. Nephrol. Dial. Transplant. 2004, 19, 2499-2504. [CrossRef] [PubMed]

229. von Wowern, F.; Berglund, G.; Carlson, J.; Mansson, H.; Hedblad, B.; Melander, O. Genetic variance of SGK-1 is associated with blood pressure, blood pressure change over time and strength of the insulin-diastolic blood pressure relationship. Kidney Int. 2005, 68, 2164-2172. [CrossRef] [PubMed]

230. Busjahn, A.; Seebohm, G.; Maier, G.; Toliat, M.R.; Nurnberg, P.; Aydin, A.; Luft, F.C.; Lang, F. Association of the serum and glucocorticoid regulated kinase (sgk1) gene with QT interval. Cell. Physiol. Biochem. 2004, 14, 135-142. [CrossRef] [PubMed]

231. Schwab, M.; Lupescu, A.; Mota, M.; Mota, E.; Frey, A.; Simon, P.; Mertens, P.R.; Floege, J.; Luft, F.; Asante-Poku, S.; et al. Association of SGK1 gene polymorphisms with type 2 diabetes. Cell. Physiol. Biochem. 2008, 21, 151-160. [CrossRef] [PubMed]

232. Chu, C.; Wang, Y.; Wang, M.; Mu, J.J.; Liu, F.Q.; Wang, L.; Ren, K.Y.; Wang, D.; Yuan, Z.Y. Common variants in serum/glucocorticoid regulated kinase 1 (SGK1) and blood pressure responses to dietary sodium or potassium interventions: A family-based association STUDY. Kidney Blood Press. Res. 2015, 40, 424-434. [PubMed]

233. Rexhepaj, R.; Boini, K.M.; Huang, D.Y.; Amann, K.; Artunc, F.; Wang, K.; Brosens, J.J.; Kuhl, D.; Lang, F. Role of maternal glucocorticoid inducible kinase SGK1 in fetal programming of blood pressure in response to prenatal diet. Am. J. Physiol. Physiol. Regul. Integr. Comp. Physiol. 2008, 294, R2008-R2013. [CrossRef] [PubMed]

234. Lang, F.; Huang, D.Y.; Vallon, V. SGK, renal function and hypertension. J. Nephrol. 2010, 23, S124-S129. [PubMed]

235. Beltowski, J.; Rachanczyk, J.; Wlodarczyk, M. Thiazolidinedione-induced fluid retention: Recent insights into the molecular mechanisms. PPAR Res. 2013, 2013, 628628. [PubMed]

236. Hong, G.Z.; Lockhart, A.; Davis, B.; Rahmoune, H.; Baker, S.; Ye, L.; Thompson, P.; Shou, Y.P.; O'Shaughnessy, K.; Ronco, P.; et al. PPAR $\gamma$ activation enhances cell surface ENaC $\alpha$ via up-regulation of SGK1 in human collecting duct cells. FASEB J. 2003, 17, 1966-1968. [PubMed]

237. Panchapakesan, U.; Pollock, C.; Saad, S. Review article: Importance of the kidney proximal tubular cells in thiazolidinedione-mediated sodium and water uptake. Nephrology 2009, 14, 298-301. [CrossRef] [PubMed] 
238. Saad, S.; Stevens, V.A.; Wassef, L.; Poronnik, P.; Kelly, D.J.; Gilbert, R.E.; Pollock, C.A. High glucose transactivates the EGF receptor and up-regulates serum glucocorticoid kinase in the proximal tubule. Kidney Int. 2005, 68, 985-997. [CrossRef] [PubMed]

239. Pavlov, T.S.; Imig, J.D.; Staruschenko, A. Regulation of ENaC-mediated sodium reabsorption by peroxisome proliferator-activated receptors. PPAR Res. 2010, 2010, 703735. [CrossRef] [PubMed]

240. Catela, C.; Kratsios, P.; Hede, M.; Lang, F.; Rosenthal, N. Serum and glucocorticoid-inducible kinase 1 (SGK1) is necessary for vascular remodeling during angiogenesis. Dev. Dyn. 2010, 239, 2149-2160. [CrossRef] [PubMed]

241. Zarrinpashneh, E.; Poggioli, T.; Sarathchandra, P.; Lexow, J.; Monassier, L.; Terracciano, C.; Lang, F.; Damilano, F.; Zhou, J.Q.; Rosenzweig, A.; et al. Ablation of SGK1 impairs endothelial cell migration and tube formation leading to decreased neo-angiogenesis following myocardial infarction. PLoS ONE 2013, 8, e80268. [CrossRef] [PubMed]

242. Das, S.; Aiba, T.; Hessler, K.; Rosenberg, M.; Xiao, C.Y.; Quintero, P.; Ottaviano, F.; Morissette, M.; delMonte, F.; Ellinor, P.; et al. Abstract 20389: Serum- and glucocorticoid-regulated kinase 1 contributes to adverse electrical remodeling by regulating cardiac $\mathrm{Na}^{+}$channels. Circulation 2010, 122, A543.

243. Feroze-Zaidi, F.; Fusi, L.; Takano, M.; Higham, J.; Salker, M.S.; Goto, T.; Edassery, S.; Klingel, K.; Boini, K.M.; Palmada, M.; et al. Role and regulation of the serum- and glucocorticoid-regulated kinase 1 in fertile and infertile human endometrium. Endocrinology 2007, 148, 5020-5029. [CrossRef] [PubMed]

244. Schmidt, S.; Schneider, S.; Yang, W.; Liu, G.; Schmidt, E.M.; Schmid, E.; Mia, S.; Brucker, S.; Stournaras, C.; et al. TGF $\beta 1$ and SGK1-sensitive store-operated $\mathrm{Ca}^{2+}$ entry and Orai1 expression in endometrial Ishikawa cells. Mol. Hum. Reprod. 2013. [CrossRef]

245. Fisher, S.J.; Giudice, L.C. SGK1: A fine balancing act for human pregnancy. Nat. Med. 2011, 17, 1348-1349. [CrossRef] [PubMed]

246. Salker, M.S.; Christian, M.; Steel, J.H.; Nautiyal, J.; Lavery, S.; Trew, G.; Webster, Z.; Al-Sabbagh, M.; Puchchakayala, G.; Foller, M.; et al. Deregulation of the serum- and glucocorticoid-inducible kinase SGK1 in the endometrium causes reproductive failure. Nat. Med. 2011, 17, 1509-1513. [CrossRef] [PubMed]

247. Cha, J.Y.; Sun, X.F.; Dey, S.K. Mechanisms of implantation: Strategies for successful pregnancy. Nat. Med. 2012, 18, 1754-1767. [CrossRef] [PubMed]

248. Zhang, S.; Lin, H.Y.; Kong, S.B.; Wang, S.M.; Wang, H.M.; Wang, H.B.; Armant, D.R. Physiological and molecular determinants of embryo implantation. Mol. Asp. Med. 2013, 34, 939-980. [CrossRef] [PubMed]

249. Lang, F.; Stournaras, C. Serum and glucocorticoid inducible kinase, metabolic syndrome, inflammation, and tumor growth. Horm.-Int. J. Endocrinol. Metab. 2013, 12, 160-171. [CrossRef]

250. Artunc, F.; Amann, K.; Nasir, O.; Friedrich, B.; Sandulache, D.; Jahovic, N.; Risler, T.; Vallon, V.; Wulff, P.; Kuhl, D.; et al. Blunted DOCA/high salt induced albuminuria and renal tubulointerstitial damage in gene-targeted mice lacking SGK1. J. Mol. Med. 2006, 84, 737-746. [CrossRef] [PubMed]

251. Wagner, C.A.; Ott, M.; Klingel, K.; Beck, S.; Melzig, J.; Friedrich, B.; Wild, K.N.; Broer, S.; Moschen, I.; Albers, A.; et al. Effects of the serine/threonine kinase SGK1 on the epithelial $\mathrm{Na}^{+}$channel (ENaC) and CFTR: Implications for cystic fibrosis. Cell. Physiol. Biochem. 2001, 11, 209-218. [CrossRef] [PubMed]

252. Lang, F.; Hoffmann, E.K. Role of ion transport in control of apoptotic cell death. Compr. Physiol. 2012, 2, 2037-2061. [PubMed]

253. Safa, K.; Ohori, S.; Borges, T.J.; Uehara, M.; Batal, I.; Shimizu, T.; Magee, C.N.; Belizaire, R.; Abdi, R.; Wu, C.; et al. Salt accelerates allograft rejection through serum- and glucocorticoid-regulated kinase-1-dependent inhibition of regulatory T cells. J. Am. Soc. Nephrol. 2015, 26, 2341-2347. [CrossRef] [PubMed]

254. Yang, X.; Yao, G.; Chen, W.; Tang, X.; Feng, X.; Sun, L. Exacerbation of lupus nephritis by high sodium chloride related to activation of SGK1 pathway. Int. Immunopharmacol. 2015, 29, 568-573. [CrossRef] [PubMed]

(C) 2016 by the authors; licensee MDPI, Basel, Switzerland. This article is an open access article distributed under the terms and conditions of the Creative Commons Attribution (CC-BY) license (http:/ / creativecommons.org/licenses/by/4.0/). 